\title{
The zooarchaeological identification of a 'Morisco' community after the Christian conquest of Granada (Spain, early 16th century): sociocultural continuities and economic innovations
}

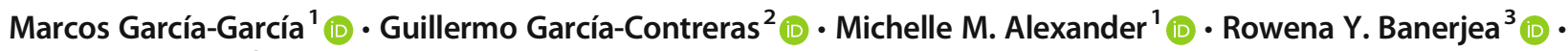 \\ Aleks Pluskowski ${ }^{3}$ iD
}

Received: 4 September 2020 / Accepted: 19 January 2021 / Published online: 2 March 2021

(C) The Author(s) 2021

\begin{abstract}
This article presents the results of the zooarchaeological analysis of an assemblage dating to the second quarter of the 16th century that was discovered on the current university campus of Cartuja, on the outskirts of Granada (Andalusia, Spain). During the Middle Ages, this area was largely used for agricultural purposes, including as estates owned by high officials of the Nasrid dynasty, the last Islamicate polity in the Iberian Peninsula. The Castilian conquest of Granada in 1492 brought significant changes to the area, with the construction of a Carthusian monastery and the transformation of the surrounding landscape, including changes in property structures, different agrarian regimes and the demolition of pre-existing structures. Among these transformations was the filling up of a well with construction materials, and its further use as a rubbish dump. This fill yielded an interesting and unique zooarchaeological assemblage, the study of which is presented here. The results advance our understanding of changing patterns in animal consumption during the formative transition from the Middle Ages to the Early Modern period at the heart of the former Nasrid Kingdom of Granada, and indicate the continuity of some Andalusi consumption patterns along with specialised production and distribution systems of meat products that have no archaeological precedent in the region, suggesting that the bones were dumped by a possible 'Morisco' community (autochthonous Muslims forced to convert to Christianity in 1502).
\end{abstract}

Keywords Early Modern period $\cdot$ Zooarchaeology $\cdot$ Meat consumption $\cdot$ Identity $\cdot$ Crypto-Muslim

\section{Historical context: from the Aynadamar estate to the university campus of Cartuja}

Development works undertaken between 2013 and 2015 to reurbanise the university campus of Cartuja, to the north of Granada's historical centre (Fig. 1), resulted in a complex archaeological project that included watching briefs and stratigraphic excavation, ranging from small sondages to largescale trenches (García-Contreras and Moreno-Pérez 2016,

Marcos García-García marcos.garcia2@york.ac.uk

1 BioArCh, Department of Archaeology, University of York, York, UK

2 Departamento de Historia Medieval, Universidad de Granada, Granada, Spain

3 Department of Archaeology, University of Reading, Reading, UK
2020). These investigations and the analysis of the associated materials enabled the archaeological sequence of this suburban area to be characterised (García-Contreras and MorenoPérez 2017).

The area currently occupied by the university campus of Cartuja must be regarded as a single multi-phase site with remains dating as far back as the Neolithic (Moreno-Pérez 2011, 2020). There was also a significant Roman industrial presence, including a major pottery kiln, but no domestic structures (Moreno-Pérez and Orfila 2017; Moreno-Pérez and Villarino 2017; Sánchez 2020), after which there was small early medieval hamlet and a necropolis that was abandoned in the 9th century (Román 2014, 2020; Román and Carvajal 2018). There is also evidence of intense occupation during the Nasrid period (13th century onwards), including the construction of houses and vegetable gardens. The area was known as the 'estate of Aynadamar', after the acequia (watercourse) built in the 11th century to supply water to the original urban nucleus of Granada, the Albaicín (Barrios 


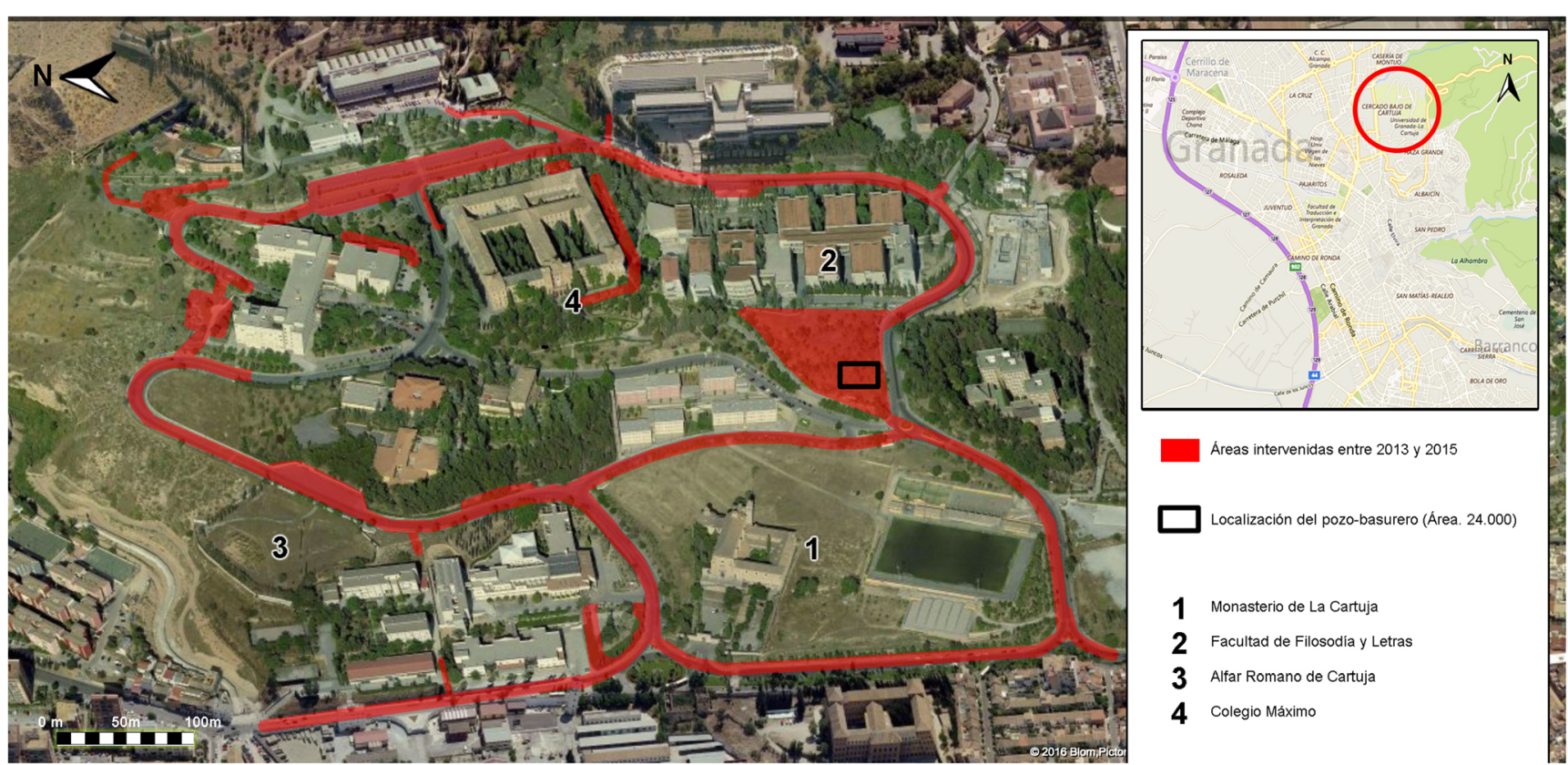

Fig. 1 In red, the area investigated in 2013-2015 (García-Contreras and Moreno-Pérez 2016). The black rectangle indicates the location of the well rubbish dump

1985; García-Contreras, in press; García-Contreras et al. 2017; Trillo 2003). There are few written references to this estate, other than Ibn Batutta's and Ibn al-Jatib's hyperbolic descriptions of the beauty of a hill covered in gardens and palatial houses (Cabanelas 1979; Tito 2018).

This landscape changed radically after the Castilian conquest in 1492, when the area was progressively acquired by Christian colonists, Italian merchants and, especially, the Carthusian Order, which built a church and a monastery and enclosed all their properties in the area, which began to be known as Cercado de Cartuja (Almagro 2010; Díaz 2019; López and Díez 2017; Rodríguez 2005; Torres 2007; Turatti et al. 2016). It is within the context of these changes that the most detailed descriptions of the previous Nasrid landscape are to be found. The written records note that cármenes - a type of suburban property comprising of a house and agricultural land - were the most common type of property, although not the only one, as these coexisted with almunias, large properties owned by the Nasrid elite for both recreational and production purposes (Boloix 2018; García-Contreras 2020; García-Contreras et al. 2020; Moreno-Pérez 2020; Román 2020; Tito 2018; Trillo 2018). The Libro de Apeo de Aguas de Aynadamar, dated to 1575, defines 'carmen' as an agricultural suburban property, used for both irrigation and dry-land agriculture, between $1 / 3$ and $2 / 3$ ha in size, which sometimes included a house, a cistern and a waterwheel, and which was often planted with vines (both, decorative and productive), which is the origin of the name: karm in Arabic (pl. kurüm), meaning 'house with vines' (Boloix 2018: 465; Corriente 1997: 459). Their owners had different social and economic backgrounds, at least according to the Castilian sources, but they seem to have mostly been artisans and merchants whose main residences were inside the city (Barrios 1985: passim; Torres 2007: passim).

Some of these owners and their descendants continued holding property in Aynadamar after the conquest. Mudéjares (Muslims under Christian rule) and, later, Moriscos (former Muslims forced to convert to Catholicism) inhabited and exploited some of these cármenes, as indicated by Christian documents dated to the 16th century: for instance, those written by the Carthusians during the process that led to the acquisition of the land for their monastery (Torres 2007) or the above-noted Apeo, dated to 1573 (Barrios 1985: 33-34; López and Díez 2017; Trillo 2018: 586). The documents mention the previous owners - mostly expelled Moriscos - and sometimes their professions (sandal makers, chair makers, bricklayers, dyers, etc.) as well as the fact that many lived in the city. To mention only two examples: in 1516, the Carthusians bought 'a vine and a haça of land and all that is contained in eight marjales, more or less, in the estate of Aynadamar' from a Françisco Ximenez (formerly known by the Muslim name Abulcaçin Mofadaen) (Torres 2007: 58). In 1530, the monks bought from 'Hernando Abendono, a merchant in Granada, parish of Sant Saluador, and his wife, a viña carmen inclusive of house and trees and three cisterns of up to thirteen marjales, water being contained in a well at the entrance of the estate' (Torres 2007: 80).

At the end of the Early Modern period, during the 19th century, the properties of Cartuja were bought by the Society of Jesus in the aftermath of the confiscation of mortmains and the dissolution of the Carthusian monastery. This period was characterised by the construction of the imposing 
seminary known as Colegio Máximo de Cartuja (Barrios 1998: 523-527). Finally, during the 1970s, this area became the university campus of Cartuja, University of Granada (Isac 2007: 122-128, 2017).

The recent archaeological investigations included the excavation of a medieval well that was reused as a rubbish pit during the early years of the 16th century. As we shall argue in this paper, the stratified deposits in the well contains unusual evidence of the transition from the Nasrid to the Castilian period, when this suburban area was, according to written sources, largely occupied by a social group comprising of former Muslims known in historiography as Moriscos.

\section{Archaeological context: the formation of a rubbish dump during the early years of the Early Modern period}

The re-urbanisation work undertaken on the university campus of Cartuja was accompanied by the opening of various sondages in those areas where the construction of new roads had the potential to affect archaeological remains. One of these trenches resulted in the discovery of the well rubbish dump, the excavation of which led to the recovery of the animal bone assemblage presented in this paper. The well is located on a rocky outcrop immediately to the west of the current Faculty of Philosophy and Humanities, and which was partially broken up to make way for the new roads and parking area. Since in some areas the natural geological level was visible on the surface and no previous archaeological remains had been reported, only a small number of trenches (numbered 21.000 to 29.000) were considered necessary. They were stratigraphically excavated (Fig. 2) and were extended where necessary in order to ascertain the relationship between the different identified features (some soundings were even linked by larger excavation trenches, e.g. 23.000 and 24.000).

The excavation revealed the presence of multiple medieval and modern features, especially at the bottom and to the west of the promontory. After the topsoil was removed by mechanical means, the whole area was stratigraphically excavated, which involved merging trenches $23.000,24.000,27.000$ and 28.000 into a single trench following the cumulativeareas approach (Carver 2009: 225). This added a horizontal perspective to the vertical stratigraphic sequence generated by the trenches, leading to the identification of a series of positive and negative features, two of which are of special interest for the purposes of this article (Fig. 3).

The first of these two features, documented in trench 29.000, was identified as a Nasrid domestic structure, which had been partially destroyed by a 19th-century road and comprised at least one room, an open courtyard paved with bricks and another small room with a small hearth. The house seems to have been occupied between the mid-14th century and the mid-16th century, and was abandoned when the surrounding agricultural area was reorganised (García-Contreras et al. 2020).

The second structure was found in trench 24.000 (later merged with others in a larger excavation area), a few metres to the west of this house. As such, it must be considered in relation to the house and other features found in the area, which are characteristic of a late medieval agricultural complex (including agricultural terraces, tree pits and water channels). These features were overlaid in the mid-16th century by more recent features, including a perimeter wall and a possible pen. The earlier features include a hydraulic structure (E4-2) and a trench (SU 24.023) truncated by a step-like cut (SU 24.033), inside which was found a well (SU 24.029) dated to the Nasrid period. All this roughly quadrangular pit is directly cut into the geological layers. After being used to draw water for some time, the well was filled up with a dump of soil, pottery, construction materials and the animal bones presented below. The sequence of fillings of this large hole in the rock starts with a reused architectural piece (SU 24.028) identified as a piece of vaulting in the Gothic style, which has played a key role in defining the chronology of the deposit that was dumped over it, as discussed further below (Villarino et al. 2016). The interstices between this architectural block and the well edges were filled with a number of shapeless blocks of bedrock, a kind of local conglomerate, along with smaller architectural pieces. After that, various soil deposits were identified: The first layer to be documented (SU 24.026) was constituted of loose dark brown soil sitting directly on SU 24.028 and filling up SU 24.027 (maximum depth $0.52 \mathrm{~m}$ ). Overlaying this layer is SU 24.020, which has yielded the most material; it is constituted of fine, loose soil which is orangey in colour. This layer is found over the whole of trench SU 24.023, filling it up completely to the top of the fill on the western end of the feature, with a maximum depth of $0.68 \mathrm{~m}$. Like the pottery, animal bones are also scattered all over the layer, but a significant concentration was attested near the top of the fill, in the central area. Two units alternating with SU 24.023 demonstrate the synchronic nature of the fill: SU 24.024 is a layer of organic soil, greyish brown in colour, rich in pebbles and construction materials, which forms a wedge along the western wall of 24.023, rising towards the SE corner. Based on the pottery, this unit is contemporary with SU 24.020, and some fragments discovered in both units have been found to match. SU 24.025 is a wedgeshaped unit immediately beneath SU 24.024 and over SU 24.020 ; it is smaller than 24.024 ( $0.93 \mathrm{~m} \mathrm{long})$ and is located in the NW area of trench 24.023. It is constituted of dark grey organic soil with abundant remains of charcoal, bones and a pottery assemblage that is equivalent to the ones in the other units. The top layer of the sequence is SU 24.021, a wedgeshaped unit abutting the NE wall of trench 24.023. It partially 
Fig. 2 Topography of the rocky outcrop on which the well rubbish dump was identified. The black line marks the course of the projected road. The green frames indicate the initial trenches opened in 2013. The areas in red indicate the extensive excavations undertaken in 2015 (GarcíaContreras and Moreno-Pérez 2016)

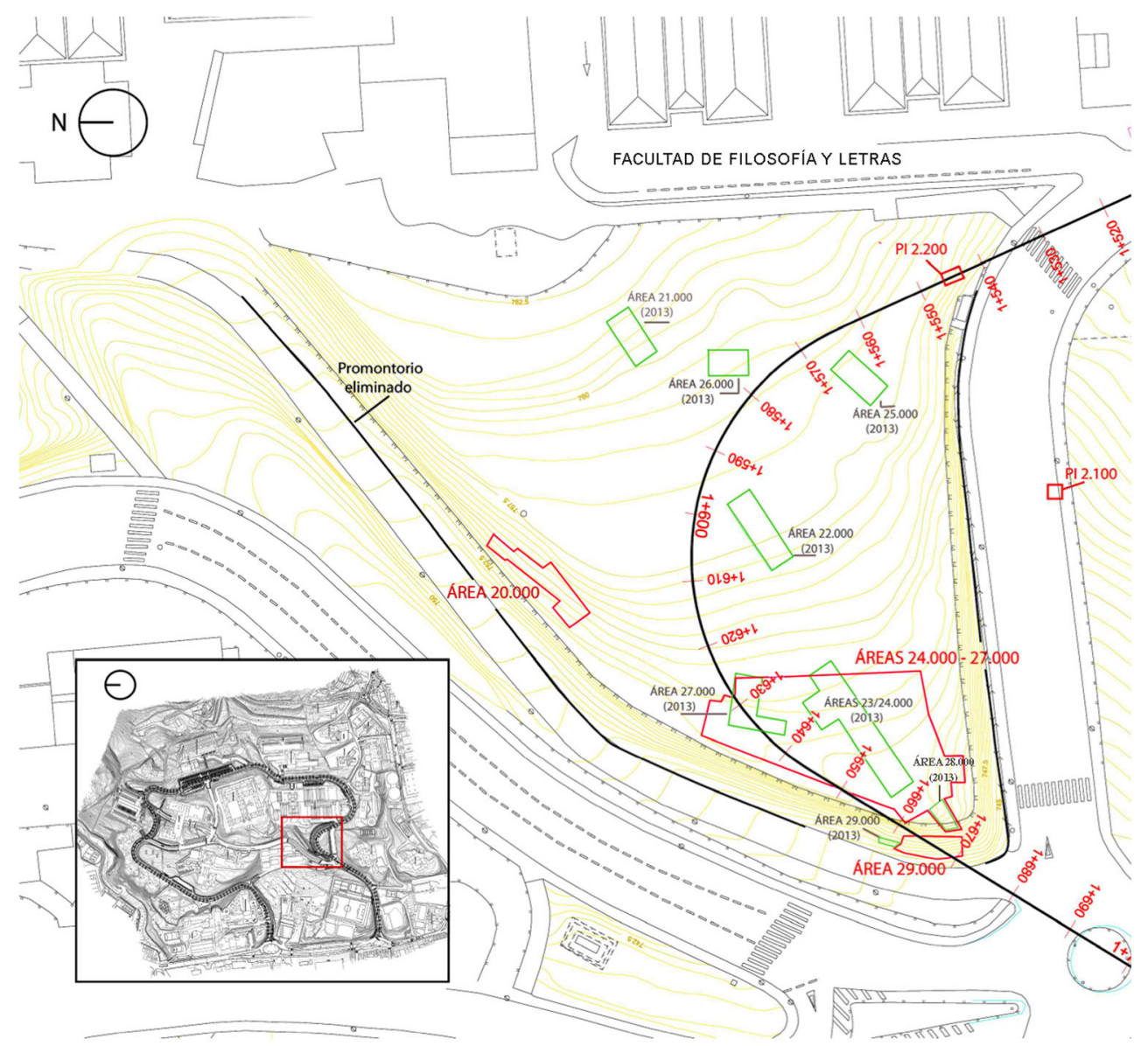

overlays SU 24.020 at the NE end of the dump, and is constituted by a compact greyish beige soil with abundant stones and pebbles - some of which have some mortar attached. This layer is the poorest unit in terms of finds. Overlaying these units is SU 24.018, a wedge-shaped unit that directly abuts SU 24.020 and 24.021, as well as SU 24.023 to the west. The presence of small- and mid-sized pebbles and abundant brick and large pottery fragments suggests that this layer may have

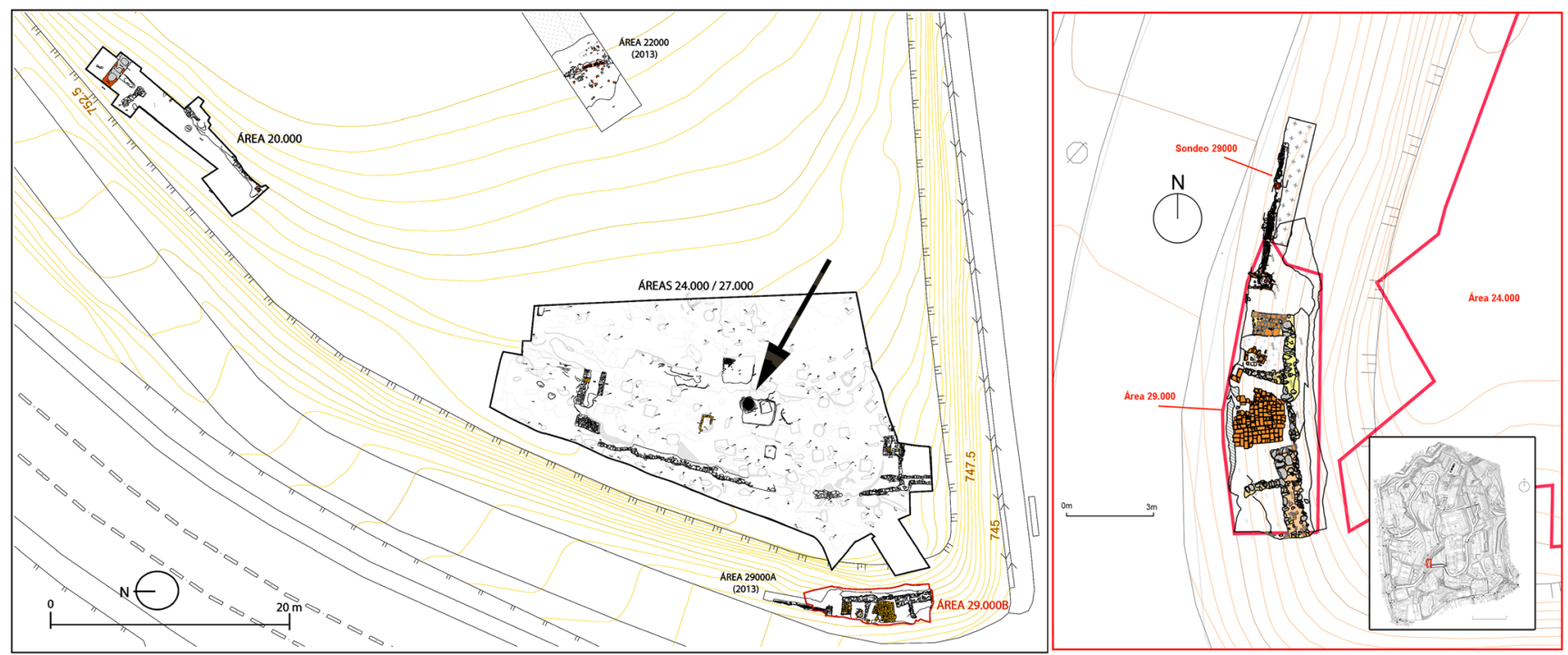

Fig. 3 Archaeological plan of the excavated area. The black arrow indicates the location of the well rubbish dump. The red box, enlarged on the right side, represents the floor plan of a Nasrid (mid 14th-mid 16th c.) domestic structure 
originated from a pavement situated immediately above and $1.10 \mathrm{~m}$ to the east of the trench; these pebbles and fragments may have been washed down the slope by erosive processes. Finally, the whole area is covered by SU 24.005, a layer of agricultural topsoil with a maximum depth of $0.59 \mathrm{~m}$. The stratigraphic sequence could be examined in detail in Figs. 4 and 5 and in previous publications (García-Contreras and Moreno-Pérez 2016; Villarino 2015; Villarino et al. 2016).

Based on this archaeological sequence, we argue that the deposit in which the zooarchaeological assemblage was found was a dump used to seal the hydraulic structure around the second quarter of the 16th century. The presence of wedged layers and pottery fragments that belong to the same vases in different units, as well as the highly fragmented state of the pottery (Villarino 2015), suggests that it was dumped in a single episode. Also, Nasrid ceramic typologies are well known and can be precisely dated (see bibliography in Villarino 2015). The types present range in the fill date from the late 13th to the late 15th century, but the presence of certain types such as the two-foil lipped saucepans suggests a predominant date late in the 15th century (Fig. 6). Finally, as noted, the construction materials used to seal the well include a Gothic vault piece that must have been used in the construction of the earlier phase of the Carthusian monastery, the socalled Cartuja Vieja, between 1513 and 1515. These works were left unfinished, and soon afterwards, the Carthusians chose a different location for their monastery, a few hundred metres to the west, where in 1519 they began work on the Monastery of the Assumption, which is still standing (Diaz 2019). The unfinished monastery (chapel and provisional dwellings) was dismantled, and the land was broken up for cultivation. The materials were reused in other constructions, including perimeter walls and bridges, and also, it seems, as seals in existing wells (Villarino et al. 2016). This architectural piece provides a post quem date for the whole sequence, since the assemblage above it is constituted of animal bones and late Nasrid, but no early Castilian, ceramics (no dishes or bowls have been found). As such, it is likely that the sequence was formed no earlier than 1519 and no later than 1550, when this fill was sealed off by later layers. Furthermore, the Ordenanzas de Granada council regulations of 1544 ordered all wells to be sealed off with debris, manure and rubbish, forbidding rubbish being dumped inside the city or near the walls, but not on the outskirts, for instance outside the gate of Elvira, where the Cartuja site is located (Ordenanzas 1552: 190-191).

Therefore, the sequence presents ideal archaeological conditions: it is spatially and chronologically defined (it was totally sealed by later deposits), it has been excavated in its entirety, and the relationships with the surrounding elements both nearby (García-Contreras et al. 2020) and in the wider landscape (García-Contreras, in press; García-Contreras et al.
Fig. 4 Lateral section of the well's stratigraphic sequence. Drawing by S. Moreno and E. Villarino, included in GarcíaContreras and Moreno-Pérez 2016 , originally published in Villarino 2015

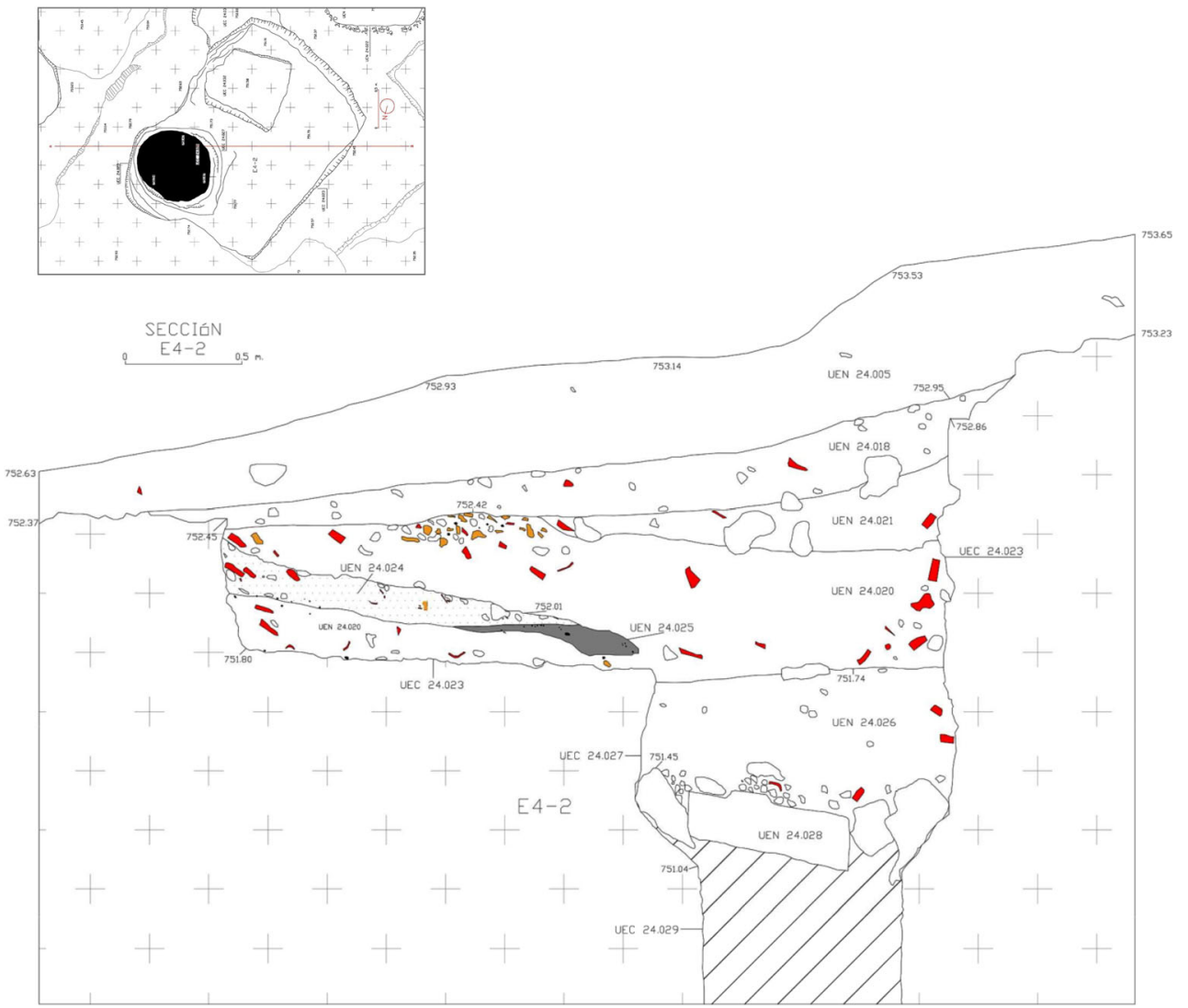


Fig. 5 Excavation sequence of the well rubbish dump E4-2
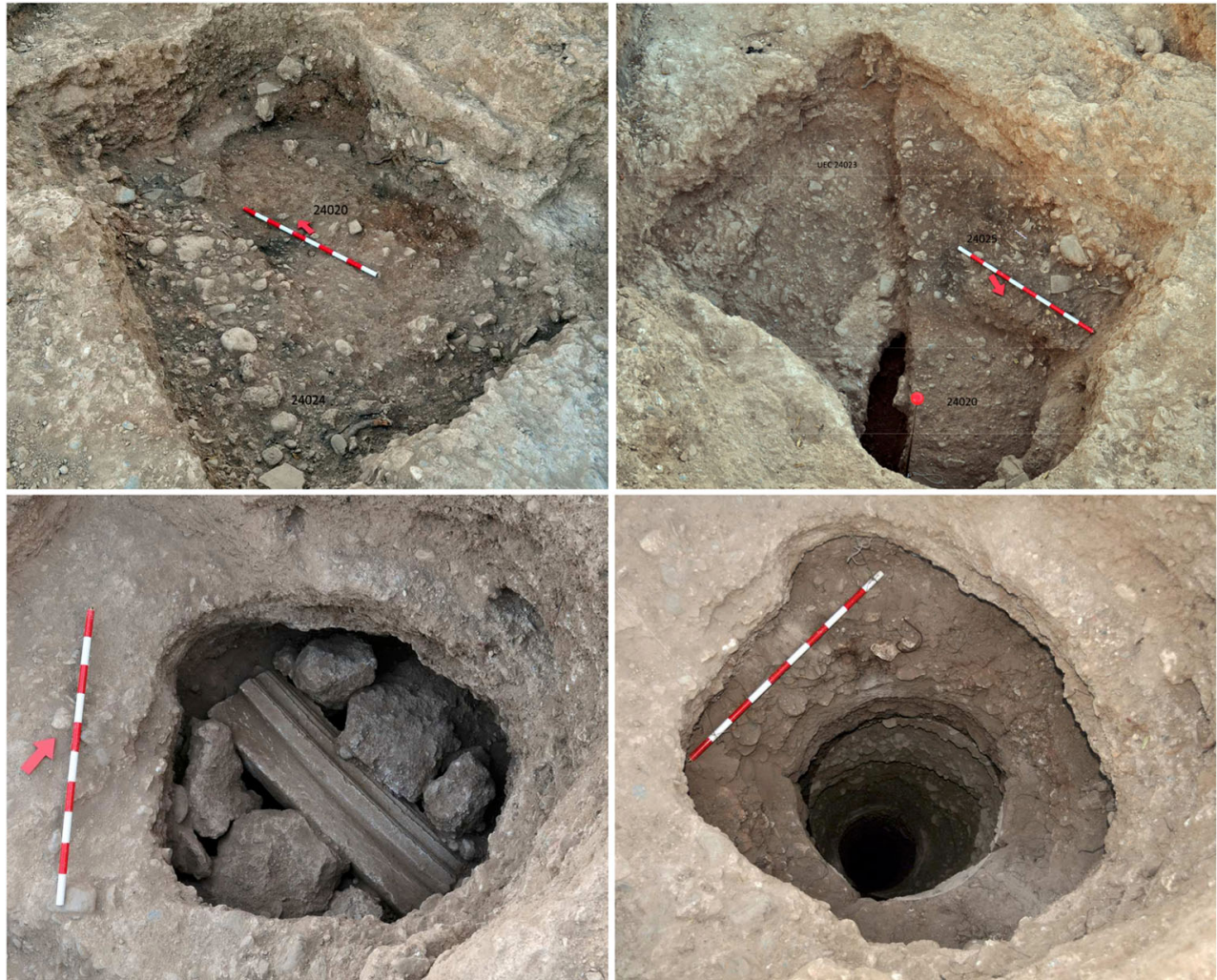

2017) are clear. For these reasons, the archaeological integrity of this assemblage enables new light to be shed on key aspects of everyday life on the outskirts of the city of Granada during the transitional period from Nasrid to Castilian rule, which saw eventual imposition of new social and religious norms.
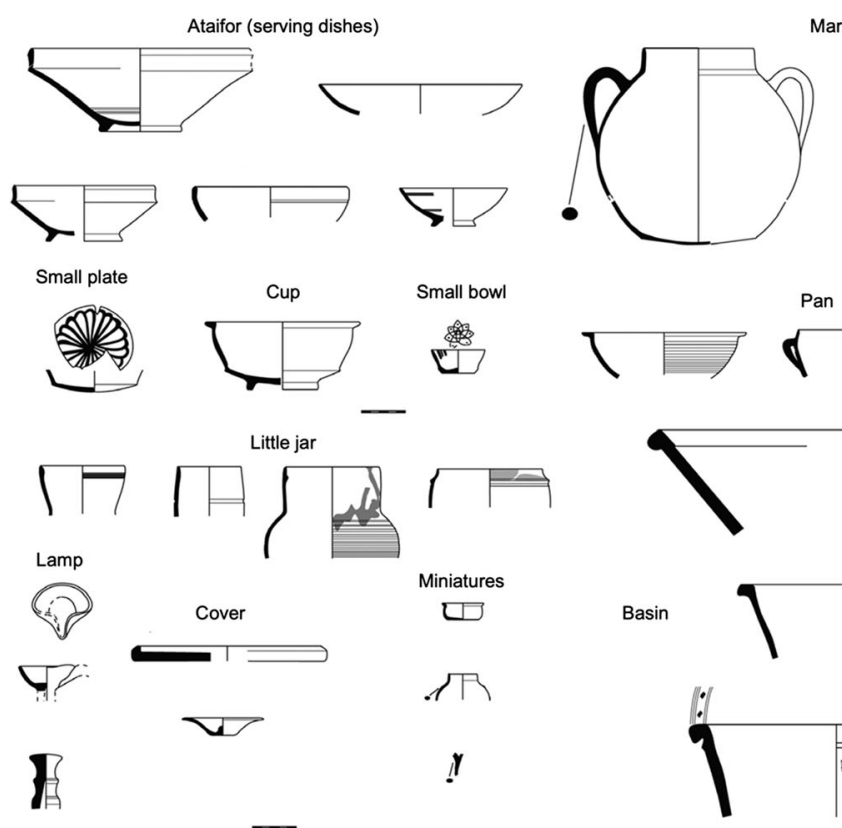

armite
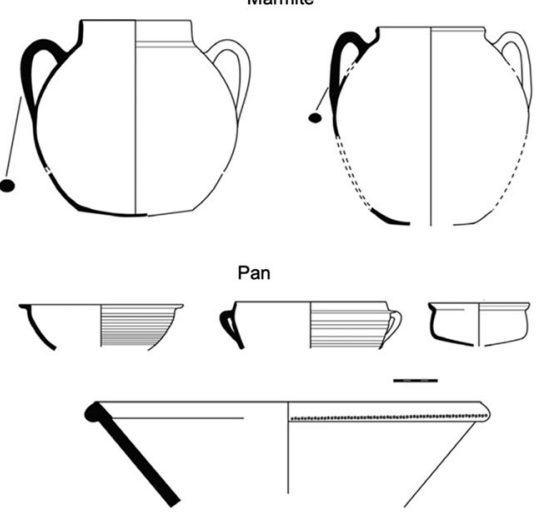

Basin
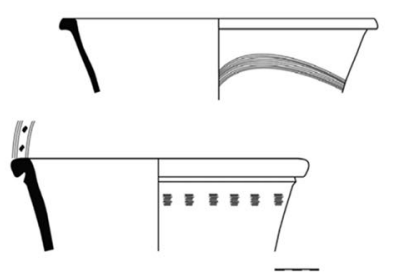
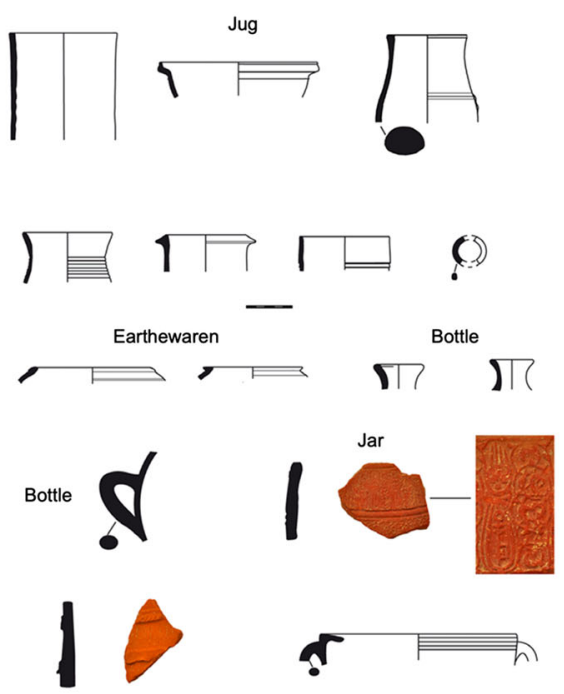

Brazier

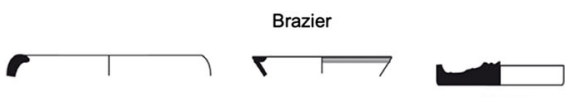

Fig. 6 Potteries recovered from the well rubbish dump. On the left, selection of tableware, lighting, complementary use and recreational use. In the centre, a selection of ceramic for cooking and multiple uses.
On the right, a selection of ceramics for storage, transport and conservation as well as fire containers or portable stoves (after Villarino 2015) 


\section{Zooarchaeological study}

\section{Methodology}

The methodology and techniques used in this study are explained in detail in García-García (2019) and can be summarised as follows:

Excavation All the bones analysed were excavated manually. As is common in rescue excavations, the investigation was limited in terms of both time and resources. Often, this limitation directly affects the recovery of smaller bone fragments and those belonging to smaller species, such as small mammals, birds, amphibians and fish (Clason and Prummel 1977; O'Connor 2001; Payne 1972, 1975); in this case, it was essential to calculate the recovery rate of the assemblage. This was undertaken by observing the frequency of certain caprine bones (the most abundant taxonomic group) of different sizes located close to one another in near anatomical position (Maltby 2010).

Identification Where possible, all the remains were identified anatomically and taxonomically with the aid of our own reference collection. The greatest challenge was to distinguish between sheep (Ovis aries) and goat (Capra hircus), for which Boessneck's (1969) and Zeder and Lapham's (2010), among other criteria, were used.

Recording All remains were divided into two main groups: identified remains (NISP) and non-identified remains. The first category includes remains that can be regarded as accountable based on an adaptation of Davis' (1992) protocols, being the main quantitative measure used. Non-identified fragments mostly belong to skull bones, non-identifiable long bones (chiefly the central diaphysis), flat bones such as the scapula (except the glenoid cavity/neck) and the pelvis (except the acetabulum), vertebrae (except the atlas and the axis), ribs, and bone splinters.

Quantification The quantitative analysis is largely based on the Number of Identified Specimens (NISP) (accountable remains). Given that, as we shall see, the results suggest that the bones analysed reached the contexts as joints of meat rather than as whole carcasses, the Minimum Number of Individuals (MNI) was not considered a valid estimation in this case. Accordingly, the NISP was used as the key variable for quantifying the assemblage, and the baseline for calculating the remaining analytical parameters.

Slaughter age As a result of the taxonomic and anatomical nature of the sample, especially the absence of mandibles, it was only possible to determine the slaughter age of caprines. This was done by examining the fusion of long bones: only epiphyses with fully formed spiculae along the surface of the epiphysis were regarded as fused. Four categories were created: 'fused epiphysis', 'epiphysis in the process of fusing', 'non-fused epiphysis' and 'non-fused metaphysis'. These categories were quantified following O'Connor (1989a) and Silver (1969).

Anatomical distribution The quantification of bones belonging to different body parts was carried out following O'Connor (2000, 2003), with the methodological modifications presented in García-García (2019), which enabled completion of an arithmetically objective quantification of significantly under- and over-represented body parts.

Carcass processing The bones presented abundant butchery marks, which were carefully recorded. All marks identified in post-cranial bones were marked on templates and counted. Their basic features (chop, cut), position on the bone (medial, joint or both) and possible aim (quartering, fleshing, extraction of internal nutrients) were also recorded (Binford 1981).

Biometric analysis Biometric analysis was limited to the morphometric characterisation of sheep post-cranial bones using the log-ratio technique (Meadow 1999; Simpson et al. 1960), using as the standard the 15th-16th century sample from The Shires, UK (Grau and Albarella 2019). Only one measurement per axis and per bone was taken for bones with less evidence of sexual dimorphism and post-fusion growth (Popkin et al. 2012). The small body of evidence available for some anatomical planes (<30 measurements) necessitated, against Davis' (1996) advice, to take into consideration the width and depth in combination.

In order to assess the size and shape of ovine bones in Cartuja, these measurements were compared with those taken in madinat Ilbīra (Granada, 9th-11th century), Cercadilla (Córdoba, 10th-11th century) (both in García-García 2019), and with measurements taken in several Basque sites dated to the 15th-18th century and analysed by Grau (2020). Comparison with Ilbira and Córdoba is justified on the basis of geographical proximity, and the Basque material is the only comparable assemblage (in terms of composition and chronology) available to date in the Iberian Peninsula.

The statistical significance of the biometric data drawn from Cartuja and the assemblages used for comparison was calculated using Mann-Whitney's nonparametric $U$ test, with Bonferroni's corrections, owing to their different size, and the non-normal distribution of the eight samples with ShapiroWilk's normality test $(p \leqq 0.05)$.

\section{Provenance}

Owing to the nature of the archaeological context, this sample is of enormous interest from a zooarchaeological perspective. 
It comes from a well-contextualised negative unit that is easy to understand from a functional perspective and free from contamination in the form of residual material (Albarella 2015; Moreno-García 2013) (Fig. 7). Therefore, the context from which the material comes enable the bone assemblage to be clearly connected with a specific chronological and cultural context.

\section{Description of sample and taphonomic considerations}

The assemblage comprises 533 fragments, 346 (65\%) of which could be identified to species (NISP). Although this does not seem a large sample in absolute terms, it is worth emphasising that the archaeological provenance of the deposit and the good state of preservation of the bones (see below) make it more representative than the overall figures would suggest.

Given that the bone remains which are the subject of this study were collected manually, it is to be expected that larger bones are over-represented. In order to estimate this bias, the number of remains corresponding to a series of post-cranial caprine bones that are anatomically close were compared. Owing to the small number of teeth, metapodial bones and phalanxes found (vid. infra), this calculation was based on the calcaneus (CA) and the astragalus (AS) alone, compared with distal tibiae (Td); theoretically, there should be one CA and one AS per Td. As presented in Table 1, the loss rate of CA+ AS is $19 \%$, reflecting a fair recovery rate.

On the other hand, taphonomic processes, which can also have an effect on the preservation of bone remains, are negligible. Bone surfaces present a good state of preservation: $90 \%$ of the fragments preserved the bone cortex intact, and in only $3 \%$ was it found to be severely altered (Fig. 8). Similarly, the presence of teeth marks corresponding to commensal
Table 1 Estimated loss rate of smaller caprine bones (calcaneus [CA] and astragals $[\mathrm{AS}])$ in relation to larger adjacent bones (distal tibias [Td])

\begin{tabular}{ll}
\hline Element & NISP \\
\hline Td & 24 \\
CA+AS & 34 \\
CA+AS (Expected) & 42 \\
Loss CA+AS (\%) & 19 \\
\hline
\end{tabular}

animals - generally attributed to dogs after the bones were disposed of but before their final deposition - is extremely low, as is that of thermo-altered bones.

This suggests that the level of preservation of the material is good, and that biostratinomic and diagenetic processes have had little impact on the assemblage. Therefore, following Villarino's (2015) conclusions about the ceramics, the archaeofaunal sample can be regarded as a primary deposit (sensu Schiffer 1983) - that is, that the bones were found where they were originally buried (Albarella 2015) — or, alternatively, that the time lapse between the time when they were originally disposed of and the final burial was very short. We thus presume that the information yielded by the assemblage offers reliable evidence concerning the dietary habits of the period in which the fill was deposited.

\section{Results}

\section{Taxonomic composition}

The bone assemblage is exclusively constituted by mammals. In fact, $95 \%$ of it comprises remains of sheep (Ovis aries) and goats (Capra hircus) and remains that could only be identified to the subfamily level as Caprinae (sheep/goat) (Table 2 and Fig. 9). Among those that could be identified to the species

Fig. 7 Excavation of SU 24020.

The concentration of animal bones, which are the subject of this study, can be clearly appreciated

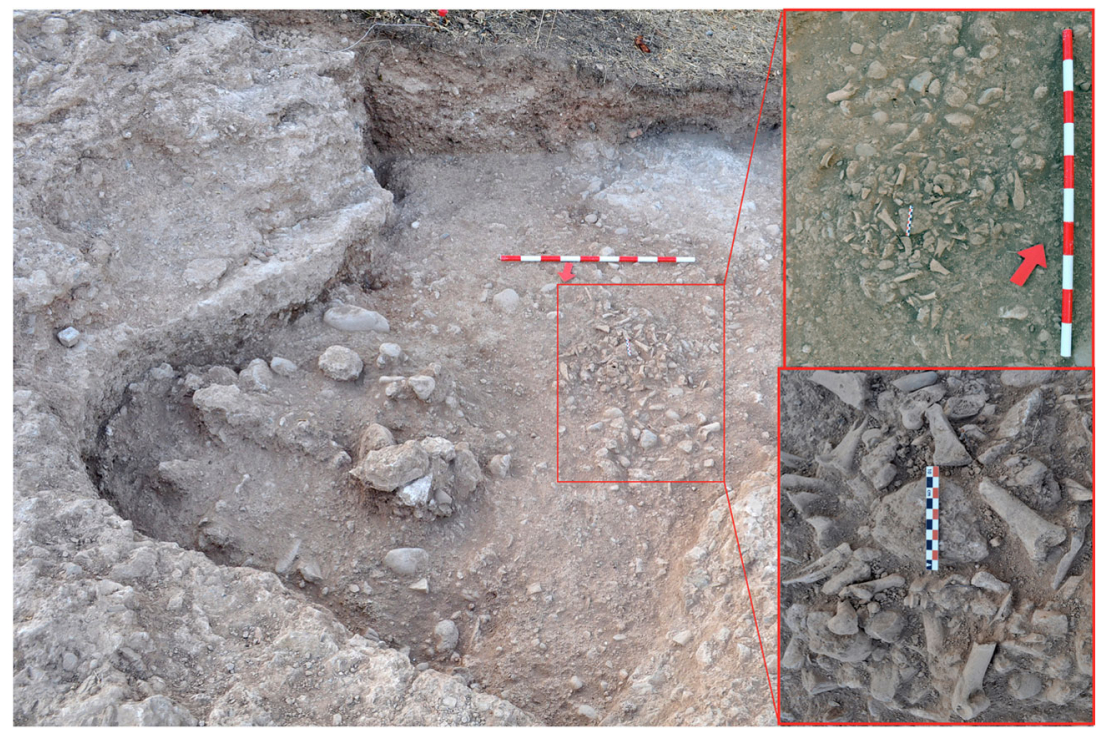


Fig. 8 Evidence for taphonomic processes (\%NISP)

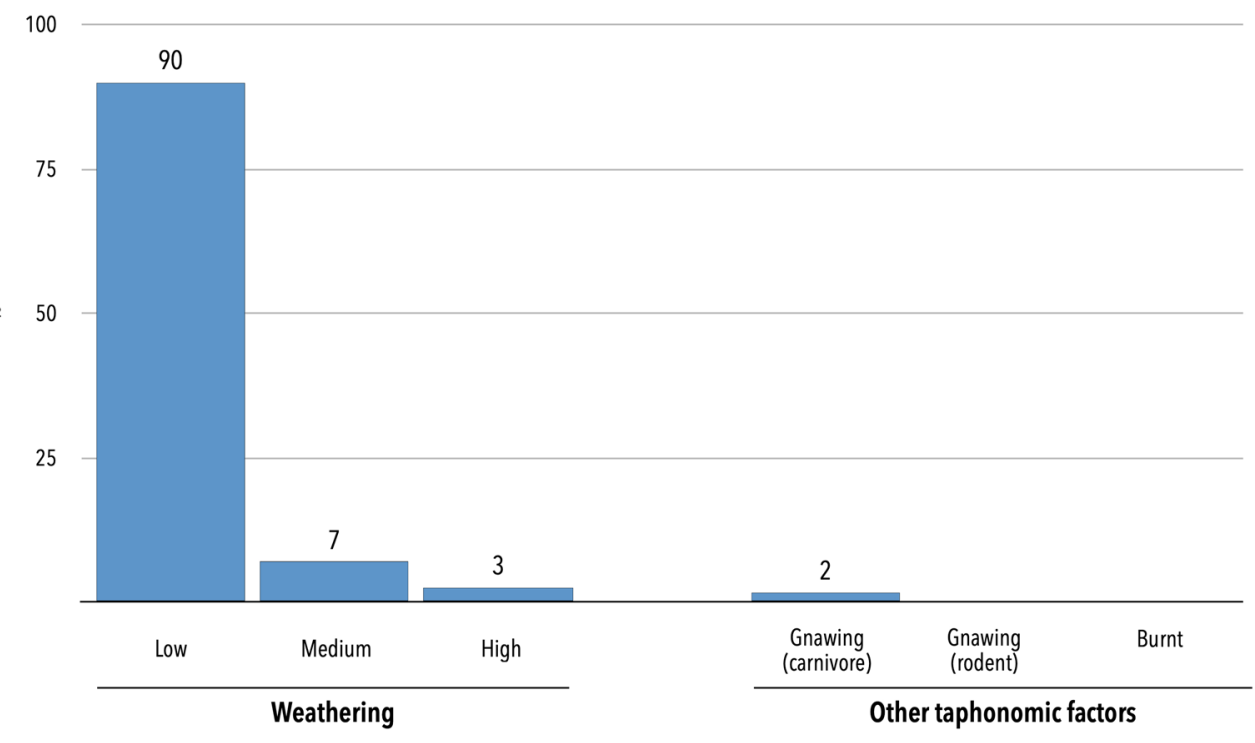

level, sheep are more abundant than goats in a proportion of 10.2:1, and so we suggest that the non-identified Caprinae are largely also sheep remains. This is thus the most represented species by a large margin.

In addition to this, the only species identified is Bos taurus (NISP $=19$ ), but the small number of remains is not representative for most of the analytical parameters examined in this study.

\section{Anatomical distribution}

Owing to the taxonomic distribution, only the anatomical distribution of Caprinae can be analysed. Sheep, goat and nondetermined Caprinae remains are considered jointly.

Before going into the matter in more detail, it is worth emphasising the good state of preservation of the assemblage, as demonstrated by the frequency of bone remains of little structural density (Symmons 2004, 2005), such as the distal radius, the proximal and distal femur, and the proximal tibia. In contrast, structurally dense elements, such as the mandible,

Table 2 Absolute and relative frequency of animal species identified (NISP). The category ' $(\mathrm{OVA}+\mathrm{CAH}+\mathrm{OVA} / \mathrm{CAH})$ ' includes all remains identified at the species and subfamily level (Caprinae), and so these values (between brackets) are not included in the overall quantification

\begin{tabular}{lll}
\hline Taxa & NISP & $\%$ \\
\hline Sheep Ovis aries & 102 & 29 \\
Goat Capra hircus & 10 & 3 \\
Caprinae Ovis/Capra & 215 & 62 \\
(OVA+CAH+OVA/CAH) & $(327)$ & $(95)$ \\
Cattle Bos taurus & 19 & 5 \\
Total & 346 & 100 \\
\hline
\end{tabular}

the teeth, the glenoid cavity and the neck of the scapula, the proximal metapodial bones, and the acetabulum of the pelvis, are under-represented (Fig. 10). This distribution suggests that the anatomical distribution is largely the result of predepositional human handling of the remains, and that taphonomic processes have had little effect on the assemblage.

As illustrated in Fig. 10, the most abundant bones in the sample are the humerus, the radius, the femur and the tibia, which suggests a well-defined pattern dominated by the middle area of both front and rear limbs. Therefore, apart from the scapula and the pelvis, the assemblage is dominated by bones from the most meat-rich areas of the animal. Also, of note is the scarcity of elements which are generally discarded in the first stages of butchering (metapodial bones and phalanxes) and the cranial region.

\section{Slaughter patterns}

The absence of mandibular bones limits the analysis of the slaughter age to the fusion of post-cranial epiphyses, which is problematic owing to the limited analytical resolution that this method affords (O'Connor 2006; Ruscillo 2014). The remains of sheep, goats and Caprinae were analysed jointly. Although considering all taxa as a single group makes it difficult to outline different management strategies, it is worth remembering that the assemblage is overwhelmingly dominated by sheep remains, and it can thus be assumed that the evidence represents husbandry practices related to this species.

The fusion curve indicates that most bones belong to adult individuals, well over 2 years of age: barely $14 \%$ of the remains presented non-fused epiphyses and thus belong to osteologically immature individuals (Table 3 and Fig. 11). Although the small number and fragmentary state of pelvic bones made it impossible to ascertain the sex of these animals, 
Fig. 9 Absolute and relative frequency of the animal species identified (NISP). The group 'Caprinae' includes the remains identified at the subfamily level (Caprinae). Data sourced from Table 2

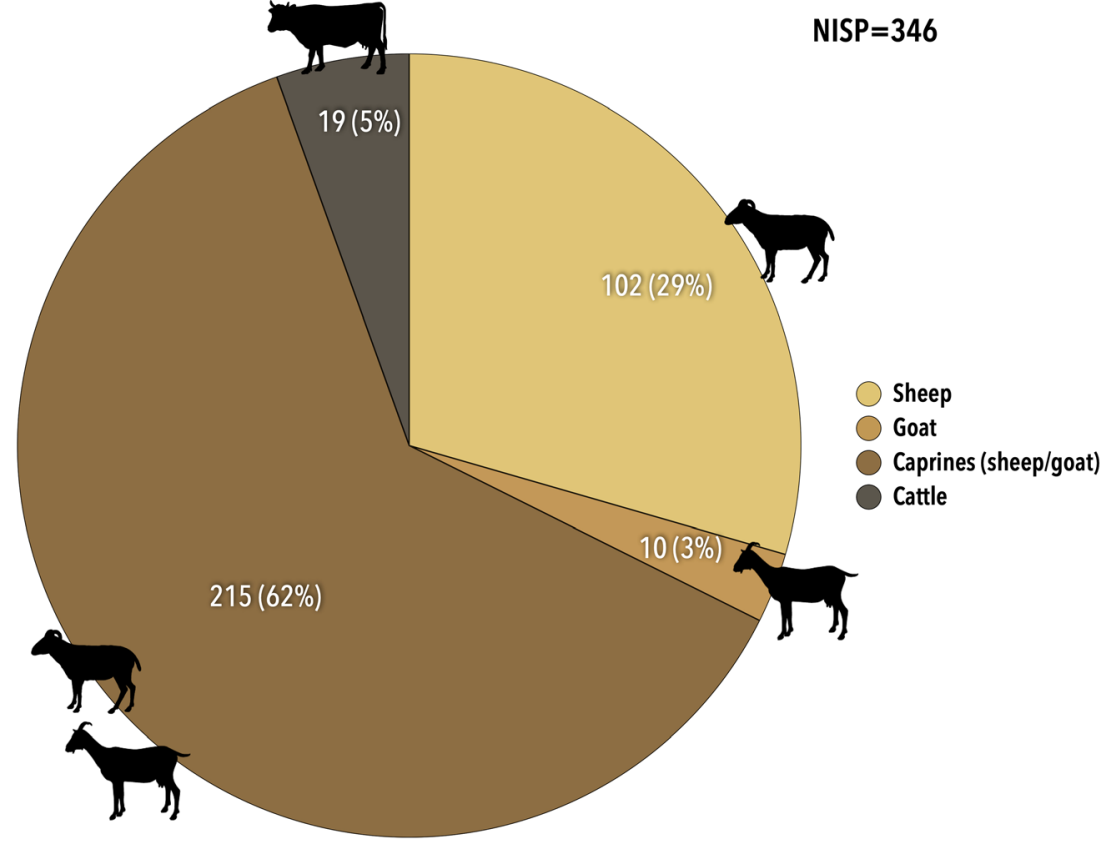

a

Anatomical elements $(\mathrm{NME}=\mathbf{2 7 4})$

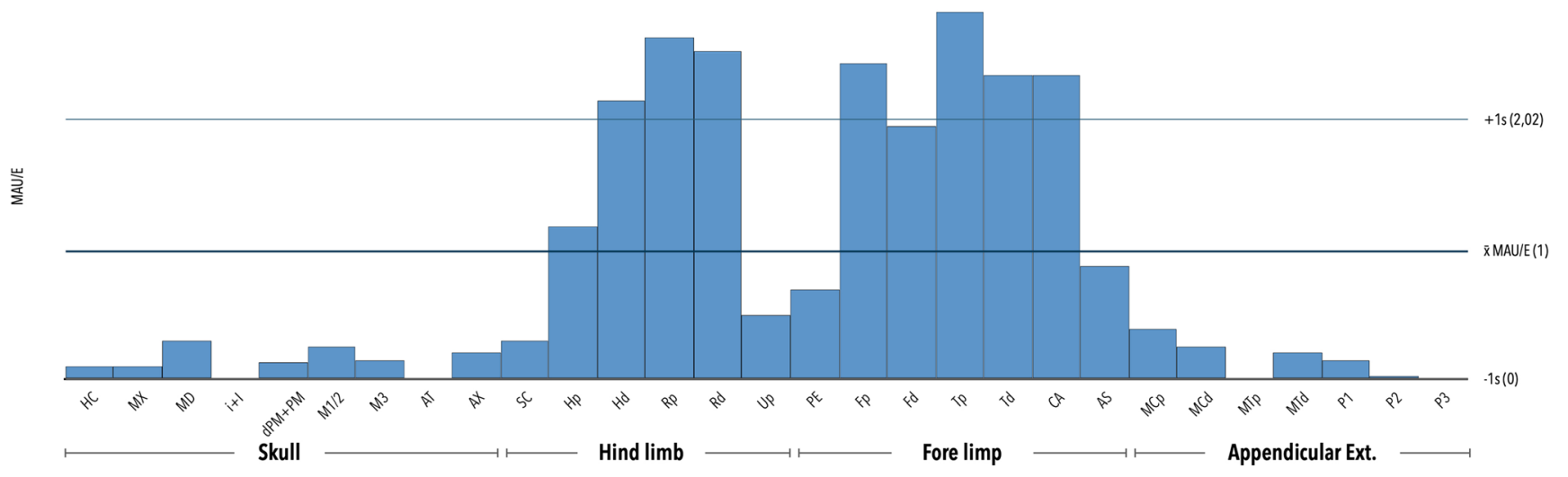

b

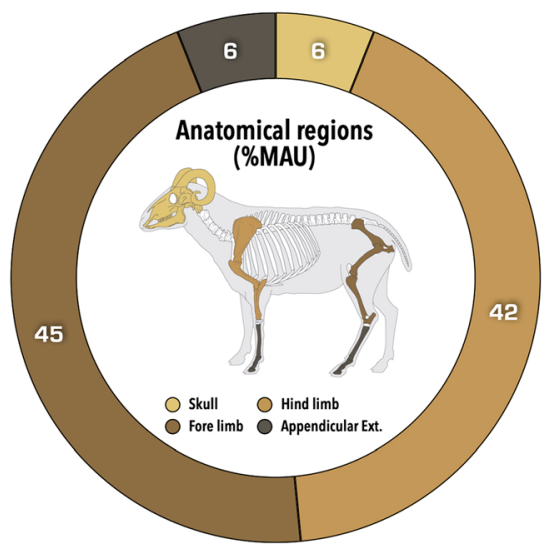

Fig. 10 Anatomical distribution of Caprinae: a abundance of anatomical elements based on MAU/E index; $\mathbf{b}$ relative abundance (\%MAU) of the main anatomical regions (the category 'Appendicular Ext.' includes

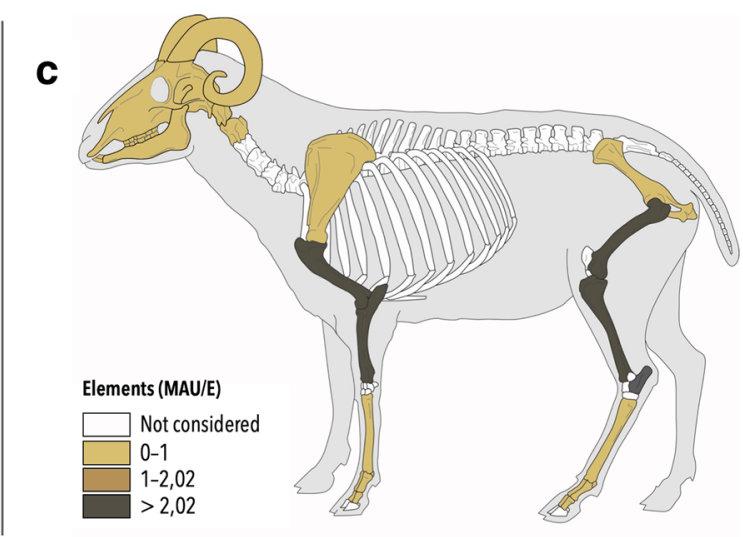

phalanxes and metapodial bones); c frequency of anatomical elements (counting whole bones) based on MAU/E index. For a detailed methodology, see García-García (2019) 
Table 3 Estimated slaughter age of Caprinae $(\mathrm{OVA}+\mathrm{CAH}+\mathrm{OVA} / \mathrm{CAH})$ based on post-cranial epiphysis fusion, reflected in adult bones ( $\mathrm{A}=$ fused bones) and juvenile bones ( $\mathrm{J}=$ non-fused bones) in O'Connor's (1989a) age groups

\begin{tabular}{|c|c|c|c|}
\hline Fusion and age groups & Element & A & $\mathrm{J}$ \\
\hline \multirow[t]{6}{*}{ Early $(<1.5$ years $)$} & $\mathrm{ESd}$ & & \\
\hline & $\mathrm{Hd}$ & 23 & 1 \\
\hline & $\mathrm{Rp}$ & 27 & \\
\hline & F1p & 7 & \\
\hline & $\mathrm{F} 2 \mathrm{p}$ & & \\
\hline & $\%$ juvenile average & 2 & \\
\hline \multirow[t]{3}{*}{ Middle (1.5-2.5 years) } & $\mathrm{Td}$ & 23 & 1 \\
\hline & MPd & 3 & \\
\hline & $\%$ juvenile average & 4 & \\
\hline \multirow[t]{8}{*}{ Late (2.5-3.5 years) } & $\mathrm{Up}$ & 1 & 2 \\
\hline & $\mathrm{Fp}$ & 13 & 4 \\
\hline & $\mathrm{CA}$ & 19 & 4 \\
\hline & $\mathrm{Rd}$ & 21 & 5 \\
\hline & $\mathrm{Hp}$ & 8 & 3 \\
\hline & $\mathrm{Fd}$ & 16 & 4 \\
\hline & $\mathrm{Tp}$ & 6 & 3 \\
\hline & $\%$ juvenile average & 23 & \\
\hline$\%$ average young animals & & 14 & \\
\hline$N$ & & 194 & \\
\hline
\end{tabular}

we shall argue further below that most of the individuals may represent castrated males slaughtered for their meat.

\section{Butchery marks}

One of the most interesting aspects of our study is the analysis of butchery marks inflicted during the quartering and carving of the animal carcasses.
Table 4 Number and frequency of butchery marks on the remains of Caprinae, by type and function. The total number of bones (expressed as NISP) excludes mandibles and teeth. The aggregate number of marks does not represent the actual number of marks identified since some remains displayed more than two types of mark

\begin{tabular}{llll}
\hline & & $\mathrm{N}$ & $\%$ \\
\hline Type & Percussion & 172 & \\
\multirow{3}{*}{ Function } & Cut & 5 & \\
& Quartering & 112 & \\
& Marrow extraction & 85 & 43 \\
Total post-cranial bones (NISP) & & \\
Total bones with marks & 252 & \\
\hline
\end{tabular}

Focusing again on Caprinae, the number of remains that present butchery marks is very high (slightly more than twothirds) (Table 4 and Fig. 12), suggesting that carcasses were intensively used. Most are percussion marks, inflicted with a heavy tool such as a hatchet or cleaver; the number of knife marks is much lower. The type, position and orientation of the marks suggest that their aim was to quarter limbs and extract the bone marrow from long bones - carving marks in the central epiphysis are notably absent.

The recording system, including drawing butchery marks on templates (Fig. 13), illustrates that butcher marks presented a clearly standardised pattern that, as we shall argue, reflects a professional meat processing and distribution system.

In summary, the data reflects the intensive use of specialised tools during butchering. The use of knives to sever the ligaments that kept the joints together is scarce, with most butchering marks being related to the use of heavier tools such as hatchets or cleavers, which were used on the joints as well as the central diaphysis to cut the limbs into smaller pieces. The absence of carving marks and the highly standardised nature of butchery practices must also be emphasised.
Fig. 11 Epiphysis fusion curve. The dots represent fused and fusing bones in each of O'Connor's (1989a) age groups whereas the figures in brackets represent the volume of remains in each category. Data sourced from Table 3

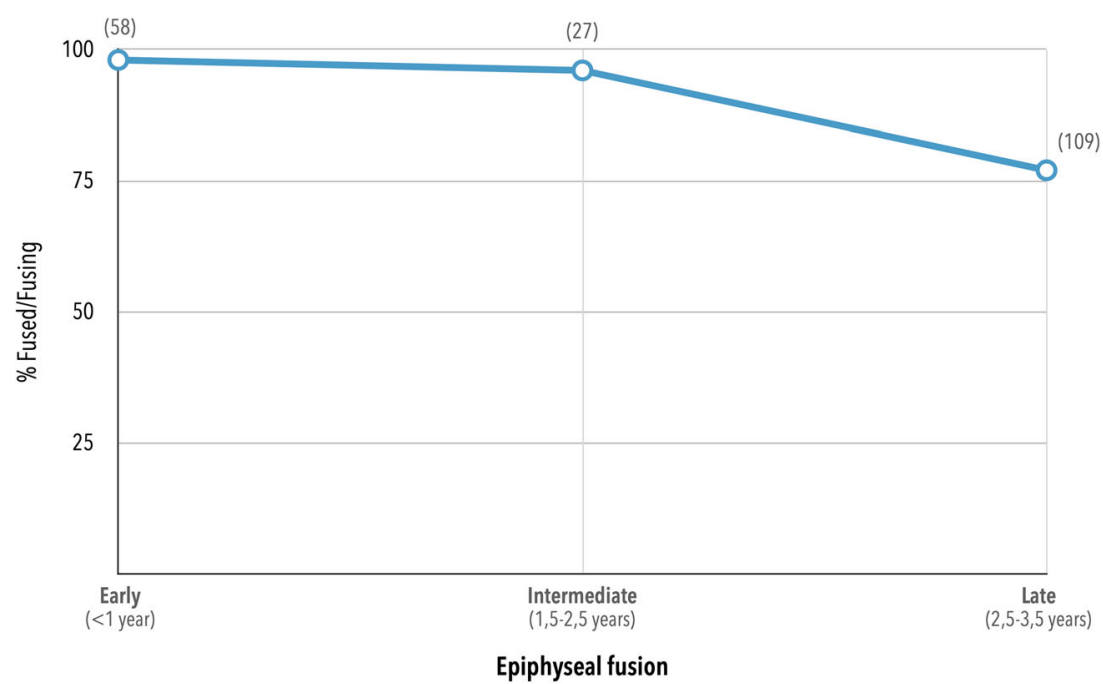


Fig. 12 Frequency and interpretation of butchery marks in the remains of Caprinae. Data sourced from Table 4

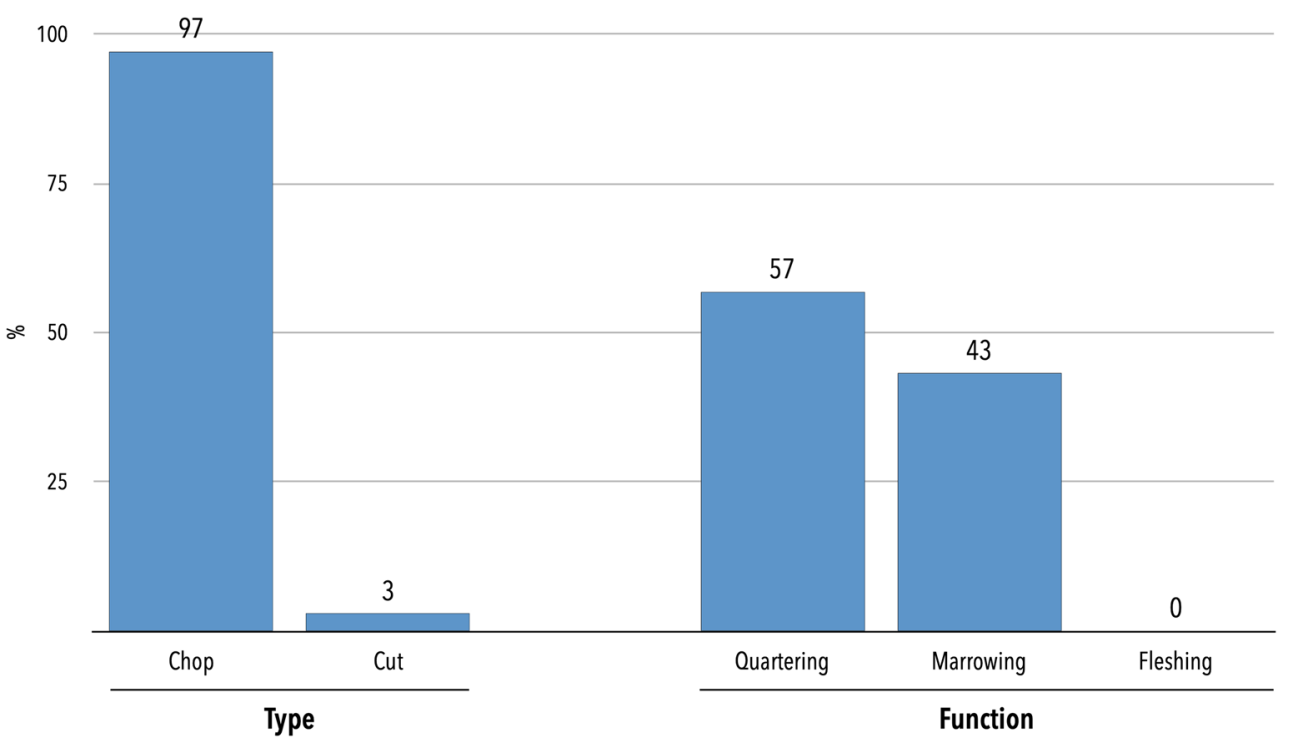

\section{Biometric analysis}

Figure 14 presents the measurements (log-ratio) corresponding to height, width and depth in the four assemblages selected for comparison. As the figures clearly express, the animals from Cartuja were the tallest (Fig. 14a) by a significant margin $(p \leqq 0.05)$ (Table 5). The width and depth measurements (Fig. $14 \mathrm{~b})$ indicate that the animals from Cartuja are similar to those from Cercadilla ( $p \geqq 0.05$ ), but they are significantly (in statistical terms) more robust than those from Ilbira and the Basque Country $(p \leqq 0.05)$.

Although the biometric analysis takes into consideration only those measurements that present less intersexual variation and post-fusion growth, we must explore the possibility that the results are a consequence of demographic differences in the various assemblages used for comparison. Since the differences are especially significant in terms of height - suggesting the exploitation of taller but similarly robust sheep-we decided to focus on the GLl (height) measurement of the astragalus, which is the only measurement that is independent of sex, age and nutrition (Popkin et al. 2012). Although the number of samples compared is not high $(N=39$, which disallows the statistical analysis of the differences observed), the GL1 values yielded by the Cartuja astragali are the highest, as expressed in Fig. 15, which seems to confirm that the animals exploited in this site were the tallest among all the examples used for comparison.

\section{Discussion}

When situated within its historical context, this zooarchaeological evidence sheds important light on the transitional period between Nasrid to Castilian rule on the outskirts of the city of Granada.

The archaeological context indicates that the bone sample was deposited when the Nasrid structures were dismantled, very likely in the second quarter of the 16th century. Both the stratigraphic position of the fill and the taphonomic features presented by the assemblage (good preservation of bone surfaces, negligible postdepositional factors) suggest that the bones were dumped inside the well not long after the remains were originally disposed of. Therefore, they plausibly represent the alimentary habits of a human group dwelling nearby, probably in the housing unit excavated in the vicinity, which included a single house, the well and an agricultural plot (carmen) (García-Contreras et al. 2020). One illustrative example of this sort of housing unit is found in a sales contract dealing with a property in the Aynadamar area in 1480:

The vineyard of al-Basțī is above the carmen ${ }^{1}$ described in this document, and the surveyors that examined the well declare that al-Bastị has dug, in the vineyard, a gallery for the evacuation of the water that irrigates his land (Seco de Lucena 1961: 73).

As such, the present study presents a unique opportunity to explore, from a local perspective and using a relatively novel approach, the historical dynamics that defined the transition between an Islamicate medieval society and the new Castilian order, which, from the late 15 th century onwards, was a

\footnotetext{
${ }^{1}$ Seco de Lucena translates both terms as 'vineyard', but we follow Amalia Zomeño's (whom we wish to thank) recommendation to translate the second term as 'carmen'.
} 

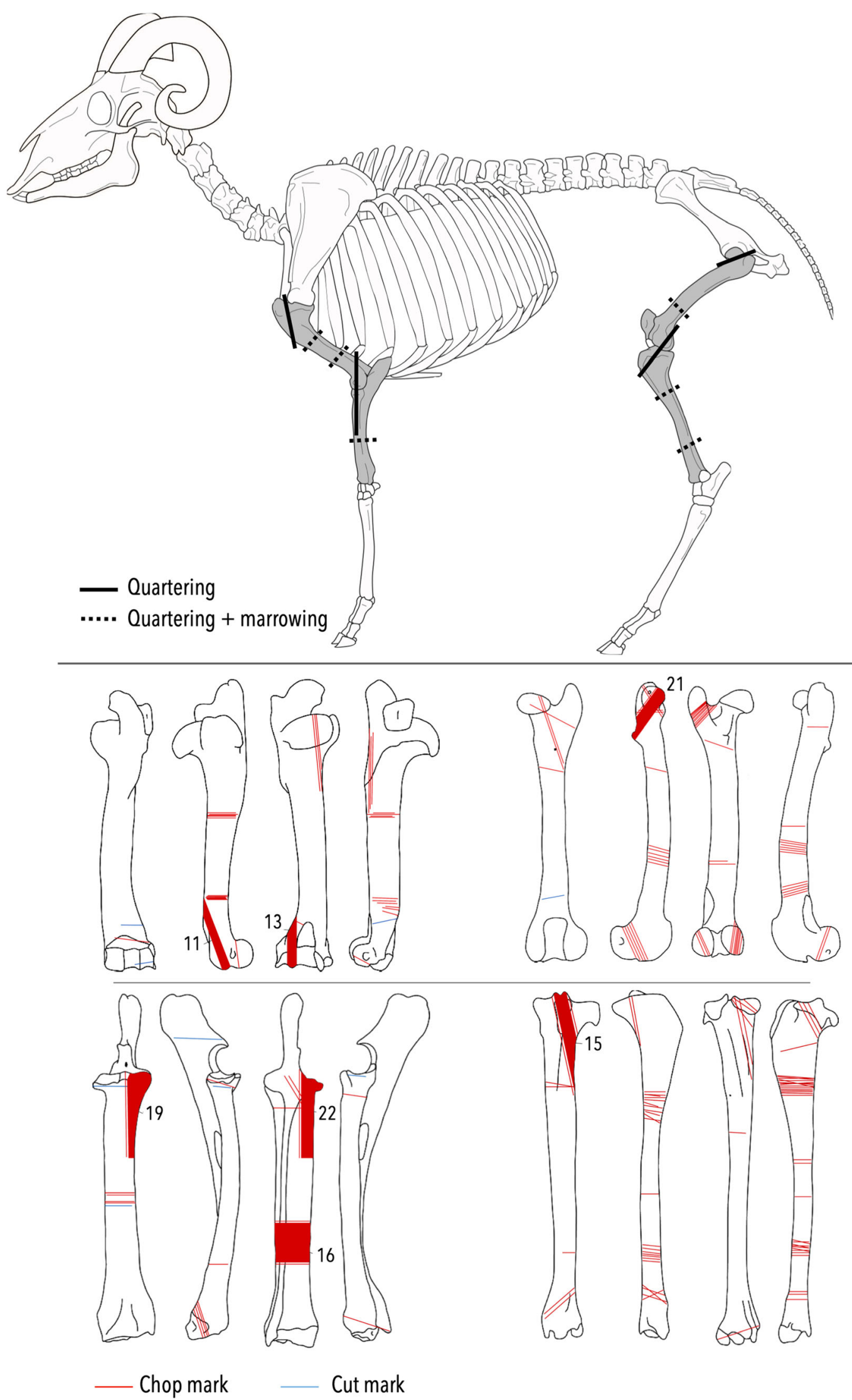

Cut mark

Fig. 13 Distribution of butchery marks on the main post-cranial elements represented in the assemblage 

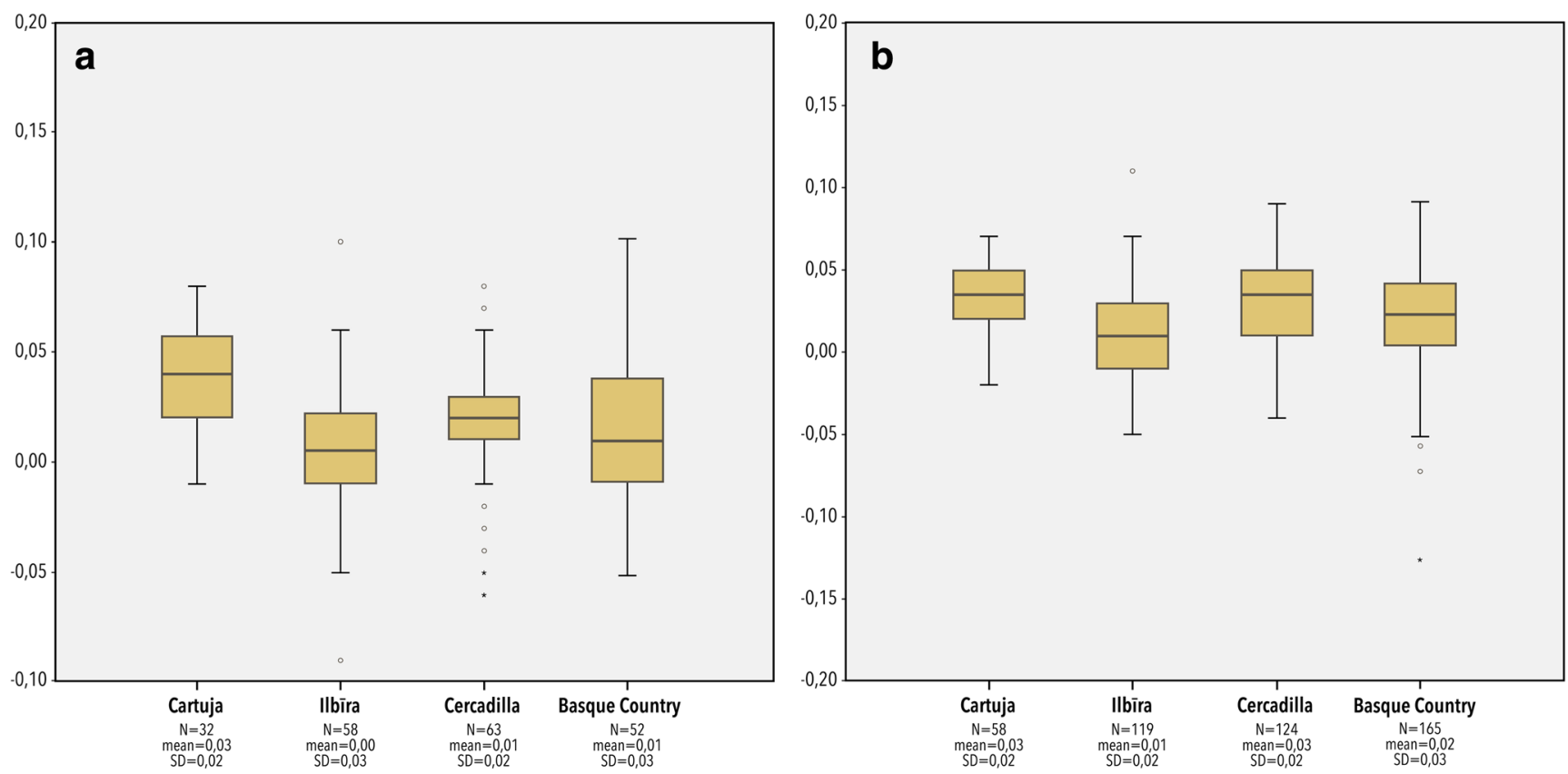

Fig. 14 Boxplots comparing height (a) and combined width and depth measurements (b) of post-cranial sheep bones (log-ratio) in Cartuja, madinat Ilbīra, Cercadilla and the Basque Country

crucial historical turning point. By focusing on such a central human activity as eating, the impact of this cultural transformation can be examined from two different perspectives, which will be addressed in order: the production and distribution of animal products, and the preparation and consumption of meat products.

\section{Production and distribution}

It is important to note that the sample examined here exclusively constitutes Caprinae bones (mostly sheep) and a few cattle bones, a species composition which sets it apart from the medieval Iberian bone assemblages analysed to date (GarcíaGarcía 2019: 632-644; Grau 2015: 122-126, et al. 2016). Apart from Suidae (pig/boar) (see below), other species common in the archaeological record at this time include chickens (generally associated with domestic exploitation) and rabbits (procured through hunting or trapping). Although their

Table 5 Statistical comparison of height and width+depth measurements of post-cranial ovine bones (log-ratio), expressing the $p$ value of the comparison between Cartuja and madinat Ilbīra (MI), absence could theoretically be associated with the manual method of collection used during the excavations, it is argued here that such possibility should be ruled out since both species are commonly found in other excavations that use a similar methodology (e.g. García-García, 2019).

The homogeneity of the assemblage being comprised of mostly sheep is thus remarkable. Previous studies have pointed out the direct relationship between the variety of species represented in an archaeofaunal sample and the level of economic centralisation of production and distribution systems. If meat is supplied through distribution mechanisms typical of complex and centralised market dynamics, the variety of species available tends to be smaller than when production is largely in the hands of consumers (Crabtree 1990; O'Connor 1989b; Wattenmaker 1987; Zeder 1988).

The data that can be used to analyse production is problematic because it is limited to the fusion of epiphyses. However, it is clear that most animals in Cartuja were slaughtered at an

Cercadilla (CER) and the Basque Country (BQ); the italicized figures represent statistically significant differences $(p \leqq 0.05)$
Kruskal-Wallis $H$ test

\begin{tabular}{llll}
\hline & Kruskal-Wallis $H$ test & \multicolumn{2}{l}{ Pairwise comparison } \\
\cline { 3 - 5 } & & CAR- & CAR- \\
CER & 0.022 & 0.018 \\
\hline Post-cranial lengths & 0.000 & 0.000 & 0.030 \\
Post-cranial width+depth & 0.000 & 0.000 & 0.472 \\
\hline
\end{tabular}


adult age as the presence of osteologically immature (infantile and juvenile specimens) bones is very low. In this regard, it must be pointed out that the abundance of immature bones $(<$ 1 year) is generally associated with the nearby presence of small-scale exploitation and with the natural pattern of mortality related to traditional stock-breeding methods. In contrast, the indirect supply of meat products is commonly reflected in the concentration of bones belonging to a single age group, normally that which provides the most meat in relation to processing/grazing investment, as is the case in Cartuja (deFrance 2009; Gumerman 1997; Zeder 1991)

The sex of these animals is unknown as the slaughter is mostly of apparently adult individuals, something which is generally associated with maximising the quantity of meat obtained, and we hypothesise that most of the bones analysed belong to castrated males slaughtered for their meat for two reasons. First, castration tends to retard the fusion of epiphyses (Davis 2000), and so it is possible that these animals were slaughtered at a younger age than the epiphysis fusion suggests (probably towards the end of their second year). Second, castration leads to larger, but not more robust, sheep bones (Davis 2000; Silberberg and Silberberg 1971), which also seems to fit with the biometric analysis of our sample and with its comparison with other assemblages. This is also in line with the written record, which indicates that castrated mutton was the most highly valued type of meat in Castile at the beginning of the Early Modern Age (year 1513, published in Alonso de Herrera 1996), and that it was common fare in Castilian markets during this period. This is also reflected in the measures enacted by the local government of Granada to guarantee its supply (de Castro 2004; Tristán 2004).

Parameters indicative of primary butchering and anatomical distribution patterns have also been taking into consideration, for which the here evidence is remarkably straightforward.

The processing and primary butchering of carcasses was established based on butchery marks. The frequency, location and orientation of these marks, especially those inflicted during quartering, suggests standardised, systematic and, therefore, professional butchering methods to a degree that has no parallels in medieval Iberian assemblages (García-García 2019; Grau 2015; Morales et al. 2011). Therefore, it is possible to suggest that primary butchering was not undertaken by the consumers - in which case, the distribution pattern of butcher marks would be less uniform and systematic - but by professional butchers. This is a typically urban pattern which may be related to the operation of markets and the centralised production of regular pieces of meat targeted at different customer groups, as established in the council regulations (Bonachia 1992; de Castro 2004; Espinar and Espinar 2014; Hernández 2006; Marín 1987).

In addition, the anatomical distribution reveals the overrepresentation of those sections of the animal that provide the most meat (middle area of the hind and rear limbs), as well as the near absence of bones that are generally discarded during primary butchering (cranial area and distal ends of limbs [O'Connor 1993]). This indicates that the rubbish dumped in well E4-2 largely constituted cooking leftovers, confirming that these remains were not processed in loco but elsewhere, and that they were only cooked and consumed nearby.

Based on these observations, it is argued that the assemblage represents cooking leftovers and a specialised production and distribution system that we may attribute to the operation of a centralised market system. This is clearly suggested by the near-exclusive presence of mutton (probably castrated), a major product in Castilian markets, including Granada, where young individuals were rare (Bernardos 2003; de Castro 2004; Hernández 2006; Tristán 2004); the predominance of meat-rich anatomical areas; and the evidence for highly standardised and specialised butchering protocols. Altogether, it seems very unlikely that the assemblage represents animals kept and produced by the consumers, but rather meat purchased in the market.

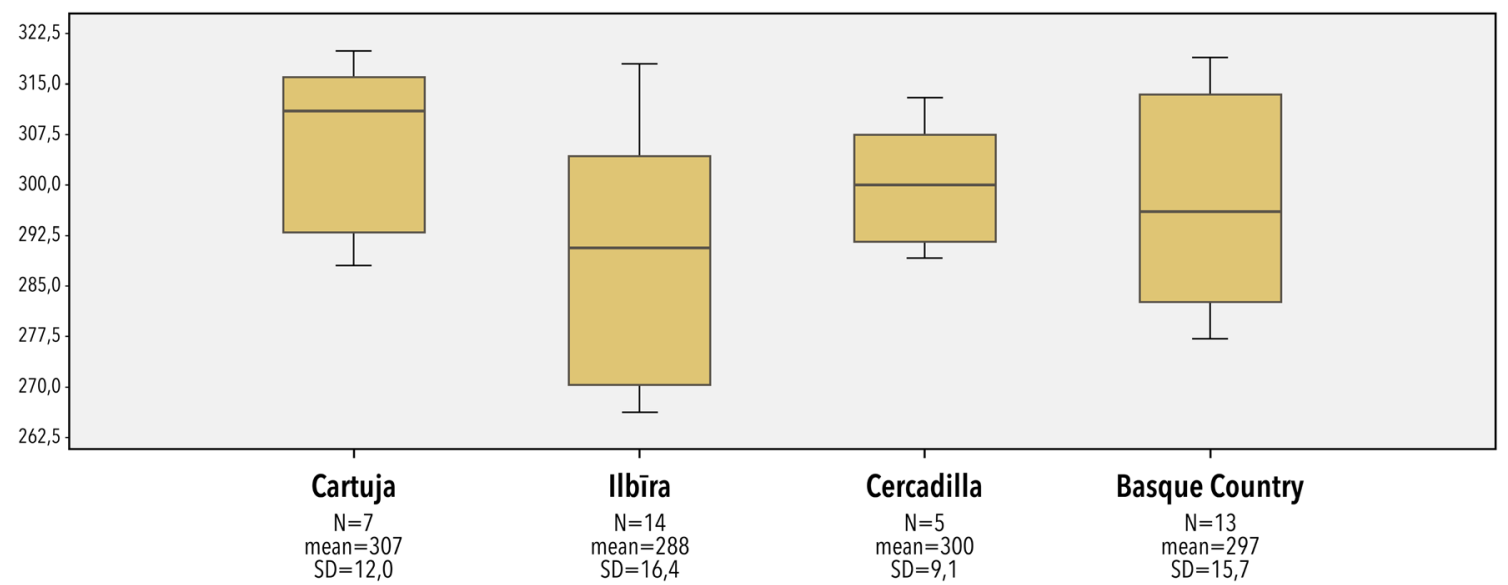

Fig. 15 Boxplot displaying the differences in the GLl measurement (greatest length of the lateral side) of astragali in the four assemblages used for comparison 

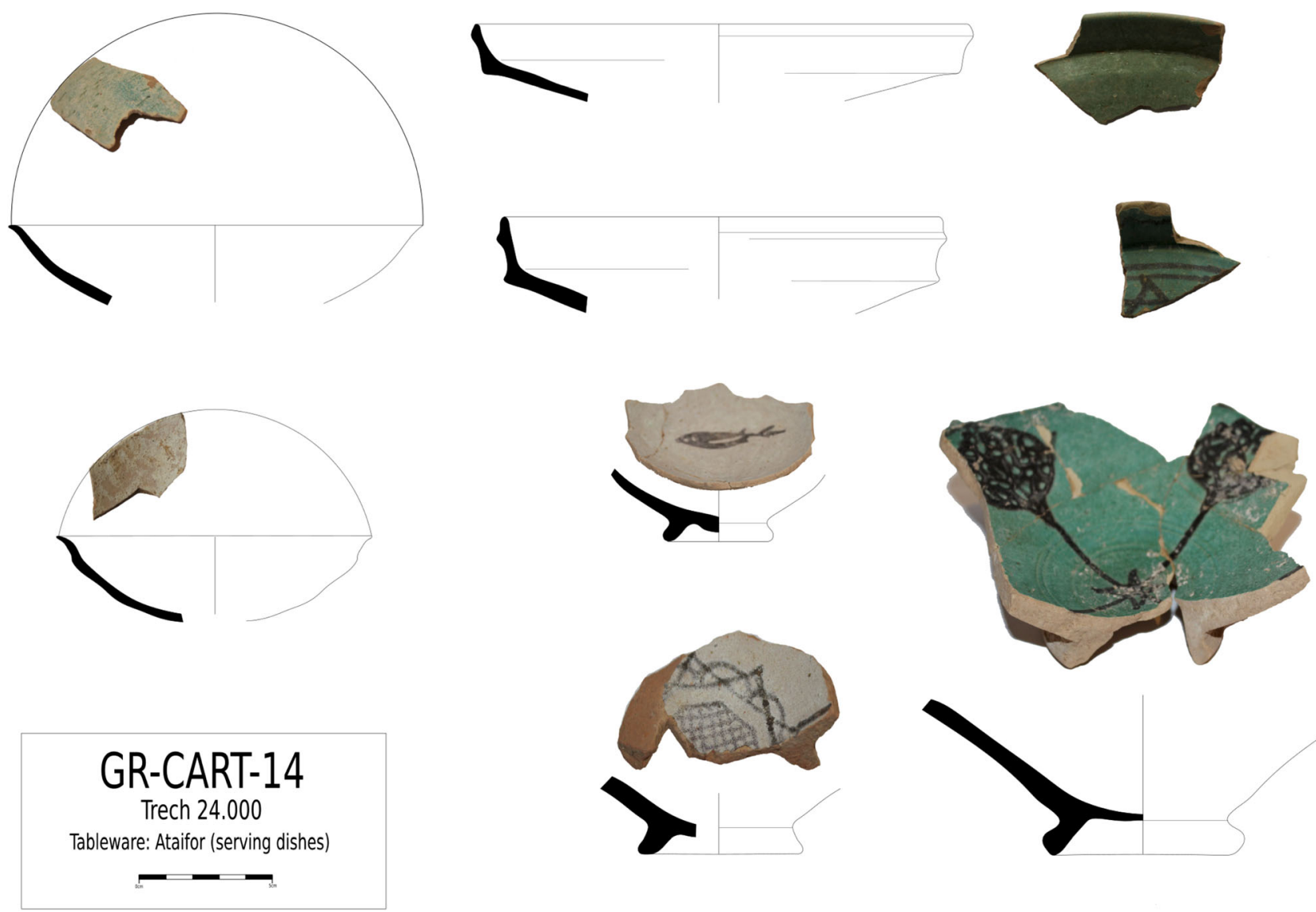

Fig. 16 Examples of large bowls (ataifores), all of them from trench 24.000 dated between 13th to 15th century

\section{Preparation and consumption}

Consideration of the social and cultural implications of this zooarchaeological assemblage draws out a number of notable aspects.

First, concerning meat preparation the small number of knife marks, which are generally associated with carving, as well as the presence of abundant percussion marks on the central area of long bones, which aimed to release internal nutrients, point to practices similar to those ethnographically documented by Burke (2000) in Lamta, a small Tunisian city, where butchers hit the central area of the diaphysis 'in order to release marrow and produce a richer broth' (ibid, p. 7). This is also in line with the aforementioned suggestion that the meat was primarily processed by professional butchers; later, the meat pieces would be prepared fresh, along with the bones and vegetables, as sauce-rich stews and broths, either in open or closed saucepans.

This can be relevantly linked to the commensality practices suggested by the ceramic repertoire found in association with the bones, which is constituted by typically late Nasrid shapes (Villarino 2015; Fig. 6). Especially of note is the presence of pieces of tableware such as ataifores (Fig. 16) or large bowls - the most abundant tableware found in Andalusi sites that was used for collective consumption around a single dish
(Alba and Gutiérrez 2008; Carvajal and Jiménez 2017; Roselló 1991) - the presence of which decreases significantly in Granada from the early 16th century onwards, being replaced by plates or smaller bowls for individual consumption (Busto 2013; Busto et al. 2017), which are virtually absent from this ceramic assemblage (Villarino 2015).

The remarkable presence of ataifores is particularly relevant, insofar as it suggests the persistent use of the most characteristic tableware in al-Andalus and thus possibly indicates the Andalusi ancestry of the human group related to the consumption of these animal products, in which case we should consider the possibility that we are dealing with a Morisco group.

There is abundant evidence to support this interpretation. As pointed out by Espadas (1975: 546), the eating habits of this social group were frequently criticised by Castilian authorities, who did not like the persistence of typically Andalusi commensality practices. Multiple sources mention social groups of Andalusi origins in relation to communal consumption habits, eating from a single dish or bowl situated in the middle of the group, directly on the floor, in the early 16th century (Constable 2013; Framiñán 2005; La Parra 2017). ${ }^{2}$ In this context, Fray

\footnotetext{
${ }^{2}$ This directly points to eating practices in the Islamicate world, as reflected in the famous hadiz 'Eat your meals together, and mention the name of Allah over it, for you will be blessed in it' (Araz 1996).
} 
Hernando de Talavera tried to educate ('domesticarles' was the word of choice used by the chronicler) noble Moriscos to 'learn to love Christian habits, sitting on chairs and eating our food', while 'giving the poor [...] tables and benches so they did not have to eat on the floor [thereby], learning our customs' (year 1639, published in Bermúdez 1989). Over time, communal eating practices were forbidden by law: the 1554 synod of Guadix forbade Moriscos 'from eating in ataifor' (Asenjo 1994). As such, the ceramic assemblage found in the site points towards the communal consumption of food and, therefore, culturally and socially Islamicate groups.

This interpretation is also in line with the zooarchaeological analysis, in particular the total absence of remains of Suidae. The evidence concerning the persistence of Islamicate alimentary habits, specifically in relation to the avoidance of pork among Moriscos is overwhelming, and is in fact one of the most reliable indicators of religious 'deviation' or cryptoMuslim (and crypto-Jewish) practices (Campbell 2017; Echevarría 2017).

Although this interpretation must be treated with a degree of caution, ${ }^{3}$ other assemblages suggest that the presence of Suidae in the Iberian zooarchaeological record can be a good indicator of the social extraction of past populations and even ethno-cultural affiliation (García-García 2019).

Figure 17 illustrates the frequency of the main taxa (Caprinae, cattle and Suidae) in bone assemblages from the Iberian Peninsula, from both Andalusi and 'Christian'4 contexts, in which the number of bone remains of these species recovered exceeded 100. Andalusi contexts are clearly dominated by Caprinae; cattle appear in small numbers, and Suidae in negligible quantities (bottom left corner). 'Christian' distributions are much less homogenous and the different species are much more evenly represented: Suidae are part of almost every assemblage. One of the only exceptions is our site, which appears towards the area of the graph populated by Andalusi samples. ${ }^{5}$

As such, both the total absence of remains of pork consumption and the ceramic evidence provide compelling

\footnotetext{
${ }^{3}$ We do not suggest that Suidae remains can be used to unequivocally identify the identity of consumer groups. In fact, it is worth pointing out that one of the most common pork products consumed in Christian (but not in Andalusi) medieval and Early Modern Iberia is pork fat (Kissane 2018), an enduring product that leaves little trace in archaeological contexts.

4 Although the term is ambiguous and too general, we use 'Christian' to refer to non-Islamicate Andalusi contexts of Late Antique, medieval and Early Modern chronology. However, we leave the term in quotation marks in order to respond to Manzano's (1994) criticism of Acién (1997; $1^{\text {st }}$ ed. 1994) for using a superstructural element such as religion to refer to a social formation.

${ }^{5}$ Three sites present a similar taxonomic composition: the Late Antique sites of Reccopolis (Olmo et al. 2019) and El Pelícano-1 (Yravedra 2008, quotation in Estaca et al. 2018), as well as a rubbish dump formed during the 15th century in Castil de los Judíos, Molina de Aragón (García-García et al. forthcoming). In our opinion, the taxonomic interpretation of the first two examples calls for the reassessment of the social context of reference, and the third suggests the survival of typically Jewish eating habits (the site was occupied by a Jewish community until the late 14 th or the early 15 th century) (Arenas 2017).
}

arguments in favour of this being a typically Andalusi consumption context. Given the historical and archaeological framework of this horizon, as well as the zooarchaeological results - particularly the high presence of skeletal elements of the hind limb and the absence of butchery marks such as those of porging attributed to Jewish communities [Lisowski 2019]) - it seems plausible that the assemblage reflects the food habits of a Morisco group.

\section{Conclusions}

This paper presented the analysis of an animal bone assemblage deposited in all likelihood during the second quarter in the 16th century on the outskirts of the city of Granada. It has been possible to broadly characterise the production, distribution, processing and consumption patterns of meat products during this period. This sample is a significant addition to the existing Early Modern period zooarchaeological corpus in the southern Iberian Peninsula, and the first example connecting culinary practices and social identity to be published from postconquest Granada that can be convincingly connected with a Morisco community.

The results of the zooarchaeological analysis are in line with those of the ceramics. Both suggest that the human group responsible for the deposit followed typically Islamicate customs. The tableware attested-which is characteristic of communal commensality practicesand the total absence of pork remains from the bone assemblage seem to point to eating habits rooted in the Andalusi milieu that preceded the Castilian conquest of the Nasrid Kingdom of Granada in 1492. In this regard, and considering the historical context, it is reasonable to suggest that the remains correspond to a Morisco group, the autochthonous population forced to convert to Christianity from 1502 onwards.

Along with these features that can be regarded as evidence of continuity in cultural practices, other elements depart from the typical features displayed by other Andalusi assemblages. Specifically, the Cartuja sample presents evidence of centralised processing and distribution of meat products: the predominance of probably male rams (likely castrated), slaughtered for their meat, and subject to highly standardised butchering practices. This corresponds to the mercantile and urban supply practices that emerged after the Castilian conquest of Granada (de Castro 2001, 2004).

In conclusion, these results suggest both cultural continuities - housing, typically Andalusi tableware and avoidance of pork - and economic innovations, represented by the centralised food-supply model established by the local council (the political representatives of the Castilian Crown). These continuities and innovations can only be understood in 


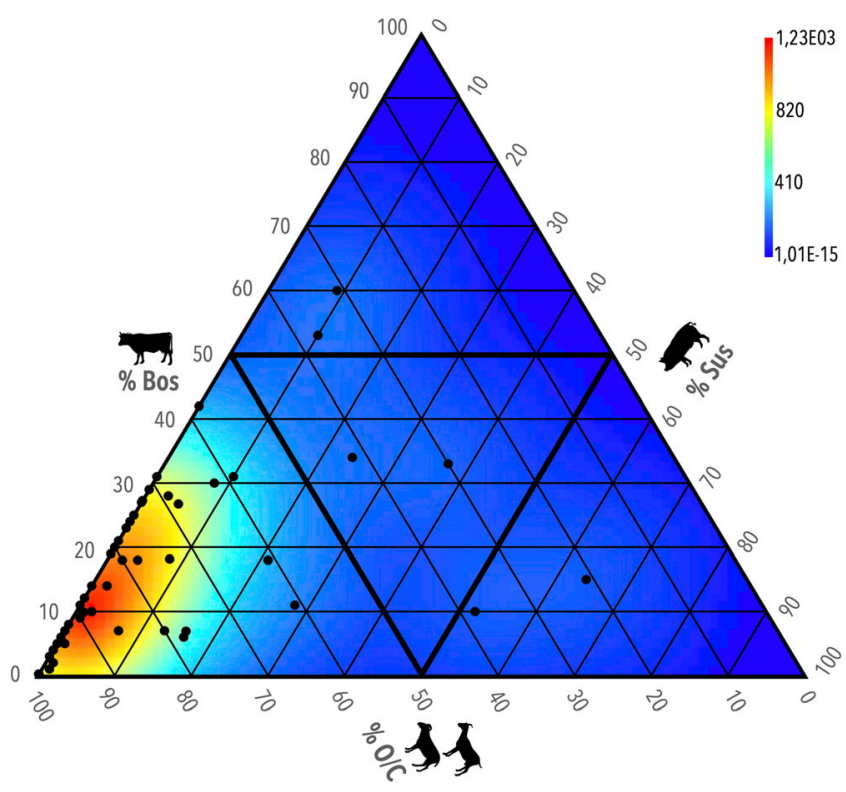

Fig. 17 Ternary graphs of the frequency of cattle $(\mathrm{Bos})$, Caprinae $(\mathrm{O} / \mathrm{C})$ and Suidae (Sus) in known Andalusi (left, $N=55$ ) and 'Christian' (right, $N=84$, see footnote 4 ) assemblages in Iberia (Spain and Portugal). Only those cases where $\mathrm{Bos}+\mathrm{O} / \mathrm{C}+\mathrm{Sus}$ remains was $\geqq 100$ NISP were

relation to the historical context and the period of transition that, in the aftermath of the conquest, resulted in the interaction of two societies linked by asymmetric power relations. This process, articulated around the 'Castilianisation' and 'Christianisation' of an Islamicate substratum, caused several tensions regarding various social practices, including eating. Ultimately, these tensions led to the expulsion of the Morisco groups from the Iberian Peninsula between 1609 and 1613.

Acknowledgements We wish to thank all the archaeologists who excavated in Cartuja, particularly in this area: C. Maeso, C. Martínez, A. González Escudero, E. Villarino, M. Gutiérrez, S. Ramírez, Á. Piña, A. Mogo and A. González Pérez.

\section{Code availability Not applicable.}

Funding This research was developed in the framework of the 'Landscapes of (Re)Conquest' Project funded by the Arts and Humanities Research Council (grant number AH/R013861/1). The archaeological excavation was funded by the Vicerretorado de Infraestructuras of the University of Granada. It was directed by G. García-Contreras Ruiz from September 2013 to August 2014, and by A. S. Moreno Pérez from September 2014 to July 2015.

Data availability The material analysed is archived at the Archaeological Museum of Granada (Spain).

\section{Declarations}

Competing interests The authors declare no competing interests.

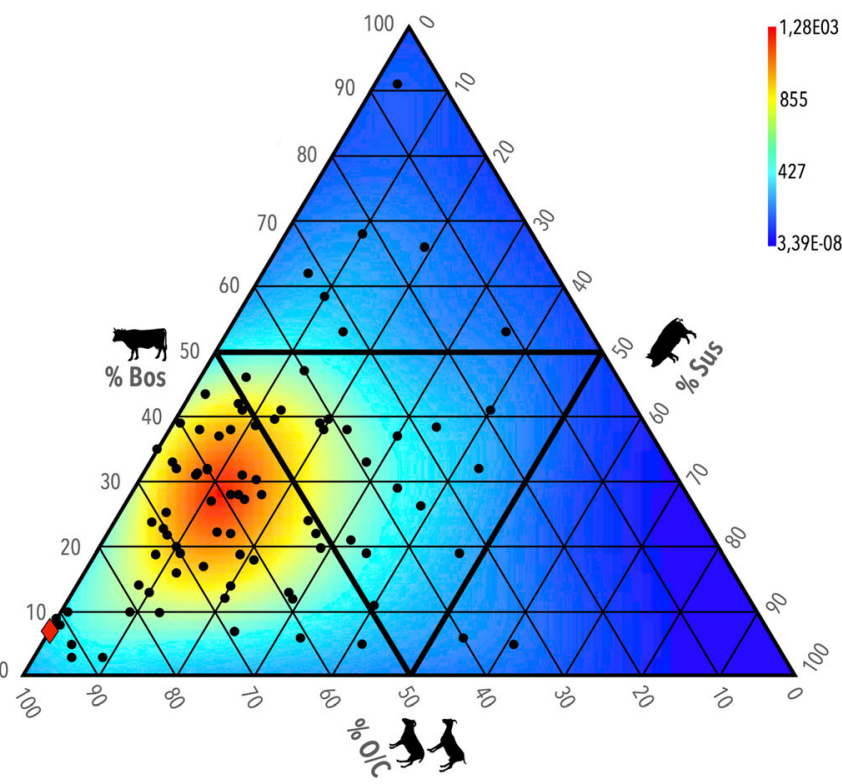

considered. Cartuja is expressed by a red diamond in the graph on the right. The complete list of sites, their location and bibliographic reference used in both graphs can be found in García-García (2019: 635-8).

Open Access This article is licensed under a Creative Commons Attribution 4.0 International License, which permits use, sharing, adaptation, distribution and reproduction in any medium or format, as long as you give appropriate credit to the original author(s) and the source, provide a link to the Creative Commons licence, and indicate if changes were made. The images or other third party material in this article are included in the article's Creative Commons licence, unless indicated otherwise in a credit line to the material. If material is not included in the article's Creative Commons licence and your intended use is not permitted by statutory regulation or exceeds the permitted use, you will need to obtain permission directly from the copyright holder. To view a copy of this licence, visit http://creativecommons.org/licenses/by/4.0/.

\section{References}

Acién M (1997) Entre el feudalismo y el islam. 'Umar b. Hafșūn en los historiadores, en las fuentes y en la historia, 2nd edn (1st ed. 1994). Universidad de Jaén, Jaén.

Alba M, Gutiérrez S (2008) Las producciones de transición al Mundo Islámico: el problema de la cerámica paleoandalusí (siglos VIII y IX). In: Bernal D, Ribera A (eds) Cerámicas hispanorromanas: un estado de la cuestión. Servicio de Publicaciones de la Universidad de Cádiz, Cádiz, pp 585-613

Albarella U (2015) Defining bone movement in archaeological stratigraphy: a plea for clarity. Archaeol Anthropol Sci 8:353-358

Almagro A (2010) Planimetría de la Cartuja de la Asunción de Nuestra Señora de Granada. Granada, Escuela de Estudios Árabes CSIC

Alonso de Herrera G (1996) Agricultura general, (1st ed. 1513). Madrid. Araz N (1996) Eat sweet, talk sweet. In: Arsel S (ed) Timeless tastes. Turkish culinary culture. Divan, Istanbul, pp 19-37 
Arenas JA (2017) El asentamiento de «El Castil de los Judíos» (Molina de Aragón, Guadalajara). Misc Estud Arabes Hebraicos 99:33-52

Asenjo C (1994) Sínodo de la Diócesis de Guadix y Baza. Universidad de Granada, Granada

Barrios M (1985) De la Granada morisca: Acequia y cármenes de Aynadamar (según el apeo de Loaysa). Granada, Diputación de Granada

Barrios JM (1998) Reforma urbana y destrucción del patrimonio histórico en Granada, Ciudad y desamortización. Granada, Editorial UGR

Bermúdez F (1989) Historia Eclesiástica de Granada, (1st ed. 1639). Editorial UGR, Granada.

Bernardos JU (2003) La ganadería española durante la Edad Moderna. Propuestas de renovación historiográfica de un sector oculto América Lat en la Hist Económica 10:39-70

Binford L (1981) Bones. Ancient men and modern myths. Academic Press, New York.

Boessneck J (1969) Osteological differences between Sheep (Ovis aries Linné) and Goat (Capra hircus Linné). In: Brothwell D, Higgs E (eds) Science in Archaeology, 2nd. Thames \& Hudson, London, pp 331-358

Boloix B (2018) Las almunias nazaríes a través de las fuentes árabes. In: Navarro J, Trillo C (eds) Almunias. Las fincas de las élites en el Occidente Islámico: poder, solaz y producción. Editorial UGR, Granada, pp 463-486

Bonachia JA (1992) Abastecimiento urbano, mercado local y control municipal: La provisión y comercialización de la carne en Burgos (siglo XV). Espac Tiempo y Forma, Ser III, Ha Mediev 5:85-162

Burke A (2000) Butchery of a sheep in rural Tunisia (North Africa): repercussions for the archaeological study of patterns of bone disposal. Anthropozoologica 32:3-9

Busto M (2013) Una aproximación a las cerámicas recuperadas en la excavación arqueológica del restaurante de «el Polinario». Arqueol y Territ 10:117-132

Busto M, García A, Lentisco JD, Linares MJ (2017) Trasformazioni sociali e produzioni ceramiche nel Regno di Granada tra l'epoca islamica e quella cristiana (Secc. XIII-XVII). In: Atti $48^{\circ}$ Convegno internazionale della ceramica 2015. In: Confronto dai castelli e dagli insediamenti: contesti rurali e urbani a confronto (X-XI secolo). Centro Ligure per la storia della Ceramica, Albisola, pp 5-23

Cabanelas D (1979) Los cármenes de Aynadamar en los poetas árabes. In: Estudios sobre Literatura y Arte dedicados al profesor Emilio Orozco Díaz. Granada, Editorial UGR, pp 209-219

Campbell J (2017) At the first table. Food and social identity in Early Modern Spain. University of Nebraska Press, Lincoln

Carvajal JC, Jiménez M (2017) Cuisine, islamisation and ceramics in the south and east of Al-Andalus. In: Vroom J, Waksman Y, Van Oosten R (eds) Medieval Masterchef. Archaeological and historical perspectives on Eastern cuisine and Western foodways. Brepols, Turnhout, pp 33-62

Carver M (2009) Archaeological investigation. Routledge, London-New York

Clason AT, Prummel W (1977) Collecting, sieving and archaeological research. J Archaeol Sci 4:171-175

Constable OR (2013) Food and meaning: Christian understandings of Muslim food and food ways in Spain, 1250-1550. Viator 44:199236

Corriente F (1997) A Dictionary of Andalusi Arabic. Brill, Leiden-New York-Köln

Crabtree P (1990) Zooarchaeology and complex societies: some uses of fauna analysis for the study of trade, social status and ethnicity. Archaeol Method Theory 2:155-205

Davis SJM (1992) A rapid method for recording information about mammal bones from archaeological sites AML Rep:19/92

Davis SJM (1996) Measurements of a group of adult female Shetland sheep skeletons from a single flock: a baseline for zooarchaeologists. J Archaeol Sci 23:593-612. https://doi.org/10. 1006/jasc. 1996.0056

Davis SJM (2000) The effect of castration and age on the development of the Shetland sheep skeleton and a metric comparison between bones of males, females and castrates. J Archaeol Sci 27:373-390. https:// doi.org/10.1006/jasc.1999.0452

de Castro T (2001) La organización del comercio alimentario en el Reino de Granada en la Baja Edad Media: ¿una deuda con al-Andalus? Anu Estud Mediev 31:843-865

de Castro T (2004) El abastecimiento alimentario en el Reino de Granada (1482-1510). Universidad de Granada, Granada

deFrance SD (2009) Zooarchaeology in complex societies: political economy, status, and ideology. J Archaeol Res 17:105-168. https://doi. org/10.1007/s10814-008-9027-1

Díaz JA (2019) La Cartuja de la Asunción (Granada). Datos inéditos para la revisión de su historia. Arch Teol Grana 82:7-68

Echevarría A (2017) Food as custom among Spanish Muslims: sources to Inquisitorial material. In: Weltecke D (ed) Essen und Fasten/Food and Fasting. Böhlau Verlag GmbH \& Cie, Köln, pp 89-109

Espadas M (1975) Aspectos sociorreligiosos de la alimentación española. Hispania 35:537-566

Espinar M, Espinar M (2014) Carnicerías y alimentación de Baza y su tierra en la primera mitad del siglo XVI. Estud sobre patrimonio, Cult y ciencias Mediev 16:121-152

Estaca V, Malalana A, Yravedra J, Linares GJ, Morín J (2018) Economic implications of livestock management strategies in the center of the Iberian Peninsula, Tagus Basin, and Mancha Alta region between the VIII and XI centuries AD. Archaeol Anthropol Sci 11:1289 1305. https://doi.org/10.1007/s12520-018-0607-9

Framiñán MJ (2005) Manuales para el adoctrinamiento de neoconversos en el siglo XVI. Criticón 93:25-37

García-Contreras G (2020) Arqueología en el entorno del Albercón de Cartuja. Cuad Tec de Patrim 11:101-114

García-Contreras G (in press) En los márgenes de la ciudad nazarí: paisaje y poder en el Pago de Aynadamar. In: García A, Fábregas A (eds) Actas del Congreso Internacional Poder y Comunidades rurales en al-Andalus y el Magreb (siglos XII-XV). Granada, Editorial UGR

García-Contreras G and Moreno-Pérez AS (2016) Informe y memoria de la I.A.P. mediante excavación y control arqueológico de movimiento de tierras en las obras de reurbanización del campus universitario de Cartuja. Agosto de 2013-Julio de 2015. Informe depositado en la Delegación de Cultura de la junta de Andalucía en Granada, $N^{\circ}$ expediente 6014. Unpublished report.

García-Contreras G, Moreno-Pérez AS (2017) Secuencia histórica del campus universitario de Cartuja. El norte de Granada a la luz de la intervención arqueológica realizada entre 2013 y 2015. Antiqvitas 29:163-182

García-Contreras G, Moreno-Pérez AS (2020) Arqueología en la reurbanización del Campus de Cartuja. Cuad Tec de Patrim 11: $81-98$

García-Contreras G, Martínez C, Malpica A (2017) Los carmenes del pago de Aynadamar: el campus de Cartuja en tiempos de alAndalus. In: Orfila M, Bellido ML (eds) Cronica de un Paisaje. Granada, Descubriendo el Campus de Cartuja. Editorial UGR, pp 26-33

García-Contreras G, Martínez C, González A (2020) Un Carmen Nazarí en Aynadamar. El registro arqueológico del desaparecido Cerro de los Almendros en el campus universitario de Cartuja (Granada). Nailos Estud Interdis de Arq 6:123-159

García-García M (2019) Explotación y consumo de los animales en el sudeste de la península ibérica durante la Alta Edad Media (siglos VII-XII): perspectivas históricas y arqueozoológicas. Universidad de Granada, Granada http://hdl.handle.net/10481/55386

Grau I (2015) The zooarchaeology of medieval Alava in its Iberian context. BAR Int. Series 2769, Oxford. 
Grau I (2020) Livestock size change and animal husbandry between the Late Middle Ages and the Modern Era in the Basque Country and its surroundings. In: Grau I, Quirós JA (eds) Arqueología de la Edad Moderna en el País Vasco y su entorno. Archaeopress, Oxford, pp $140-164$

Grau I, Albarella U (2019) The 'long' sixteenth century: a key period of animal husbandry change in England. J Archaeol Anthropol Sci 11: 2781-2803

Gumerman G IV (1997) Food and complex societies. J Archaeol Method Theory 4:105-139

Hernández P (2006) Abastecimiento y comercialización de la carne en Córdoba a fines de la Edad Media. Meridies 7:73-120

Isac A (2007) Historia urbana de Granada. Granada, Editorial UGR

Kissane C (2018) Food, religion and communities in Early Modern Europe. Bloomsbury, London

La Parra S (2017) Las comidas y los ayunos de los Moriscos. Mélanges Casa Velazquez 47:233-253

Lisowski M (2019) The identification of Jewish patterns of food preparation and consumption: a zooarchaeological approach to the Medieval and early Modern evidence from Central-Eastern Europe. PhD thesis, University of Sheffield.

López R, Díez ME (2017) Aynadamar en la Edad Moderna. El Monasterio de Cartuja y su entorno. In: Orfila M, Bellido ML (eds) Crónica de un paisaje. Granada, Descubriendo el Campus de Cartuja. Editorial UGR, pp 35-57

Maltby M (2010) Feeding a roman town. Environmental evidence from excavations in Winchester, 1972-1985. Winchester Museums, Winchester.

Manzano E (1994) Nota crítica: Entre el Feudalismo y el Islam. 'Umar ibn Hafsun en los historiadores, en las fuentes y en la historia, de M. Acién Almansa. Hispania 54:1139-1144

Marín MÁ (1987) Las carnicerías y el abastecimiento de carne en Murcia (1450-1500). Miscelánea Mediev Murc 14:49-99

Meadow RH (1999) The use of size index scaling techniques for research on archaeozoological collections from the Middle East. In: Becker C, Manhart H, Peters J, Schibler J (eds) Historia Animalium ex Ossibus. Festschrift für Angela von den Driesch. Verlag Marie Leidorf GmbH, Rahden/Westf, pp 285-300

Morales A, Moreno M, Roselló E, Llorente L, Morales DC (2011) 711 $\mathrm{AD}$ : ¿El origen de una disyunción alimentaria? Zo Arqueol 711 Arqueol e Hist entre dos mundos 15:303-322.

Moreno-García M (2013) Arqueozoología. In: García-Diez M, Zapata L (eds) Métodos y técnicas de análisis y estudio en arqueología prehistórica. De lo técnico a la reconstrucción de los grupos humanos. Universidad del País Vasco, Vitoria, pp 346-366

Moreno-Pérez AS (2011) La secuencia cultural en el solar del Centro MCC en el campus de Cartuja (Granada). Cuad de Preh y Arq de la Univ de Granad 21:323-347

Moreno-Pérez AS (2020) La excavación arqueológica en el solar del Centro de Investigación de la Mente, el Cerebro y el Comportamiento (Campus de Cartuja). Cuad Tec de Patrim 11: $45-62$

Moreno-Pérez AS, Orfila M (2017) El complejo alfarero romano de Cartuja (Granada). Nuevos datos a partir de las actuaciones arqueológicas desarrolladas entre 2014-2015. SPAL Rev de Preh y Arq de la Univ de Sev 26:139-210

Moreno-Pérez AS, Villarino E (2017) Un nuevo sector productivo en el alfar romano de Cartuja (Granada) el horno D4 y su testar cerámico. Lucentvm XXXVI:139-157

O'Connor TP (1989a) Bones from Anglo-Scandinavian levels at 16-22 Coppergate. York Archaeological Trust, York

O'Connor TP (1989b) What shall we have for dinner? Food remains from urban sites. In: Serjeantson D, Waldron T (eds) Diet and Crafts in Towns: the evidence of animal remains from the Roman to the postmedieval periods. BAR British Series 199, Oxford, pp 13-23
O'Connor TP (1993) Process and terminology in mammal carcass reduction. Int J Osteoarchaeol 3:63-67. https://doi.org/10.1002/oa. 1390030202

O'Connor TP (2000) The archaeology of animal bones. Sutton Publishing, Strout

O'Connor TP (2001) Collecting, sieving, and animal bone quantification. In: Buitenhuis H, Prummel W (eds) Animals and Man in the Past. ARC-Publicatie 41, Groningen, pp 7-35

O'Connor TP (2003) The analysis of urban animal bones assemblages: a handbook for archaeologists. York Archaeological Trust, York

O'Connor TP (2006) Vertebrate demography by numbers: age, sex, and zooarchaeological practice. In: Ruscillo D (ed) Recent advances in ageing and sexing animal bones. Oxbow Books, Oxford, pp 1-8

Olmo L, Castro M, Ruiz B, Gil MJ, Galindo MA, Checa J (2019) The construction and dynamics of Early Medieval landscapes in Central Iberia. In: Gelichi S, Olmo L (eds) Mediterranean Landscapes in Post Antiquity: new frontiers and new perspectives. Archaeopress, Oxford, pp 104-128

Ordenanzas 1552: Ordenanzas que los muy ilustres, y muy magnificos señores [sic] Granada mandaron guardar, para la buena gouernacion de su Republica: impressas año de 1552: que se han buelto a imprimir por mandado de los señores Presidente y Oydores de la Real Chancilleria de esta ciudad de Granada: año de 1670: añadiendo otras que no estauan impressas. https://bvpb.mcu.es/es/ consulta/registro.do? $\mathrm{id}=403714$.

Payne S (1972) Partial recovery and sample bias: the results of some sieving experiments. In: Higgs E (ed) Papers in economic prehistory. Cambridge University Press, London, pp 49-64

Payne S (1975) Partial recovery and sample bias. In: Clason AT (ed) Archaeozoological Studies. North-Holland, pp 7-17.

Popkin P, Baker P, Worley F, Payne S, Hammon A (2012) The Sheep Project (1): determining skeletal growth, timing of epiphyseal fusion and morphometric variation in unimproved Shetland sheep of known age, sex, castration status and nutrition. J Archaeol Sci 39: $1775-1792$

Rodríguez J (2005) La Cartuja de Granada. Patrimonio y frontera Rev del Cent de Estud Hist de Grana y su Rein 17:239-272

Román J (2014) Redescubriendo la Granada tardoantigua. Eliberri entre los siglos IV al VIII d.C. Cuad de Preh y Ar de la Univ de Grana 24: 497-533

Román J (2020) Desde íberos a jesuitas. Investigaciones en el Campus Universitario de Cartuja: La intervención arqueológica en la Facultad de Ciencias Económicas y Empresariales de Granada. Cuad Tec de Patrim 11:63-80

Román J, Carvajal JC (2018) Space, shape and recipe. Analysis of cultural change between the late Antique and the early Medieval periods in the area of Granada in light of the pottery of the excavation of the Faculty of Economics in Granada (2011-2012). Menga: Rev de Preh de Andal 4:493-507

Roselló G (1991) El nombre de las cosas en al-Andalus, una propuesta de terminología cerámica. Museo de Mallorca, Palma de Mallorca

Ruscillo D (2014) Zooarchaeology: methods of collecting age and sex data. In: Smith C (ed) Encyclopedia of Global Archaeology. Springer, New York, pp 8000-8010

Sánchez EH (2020) El Alfar Romano de Cartuja. Más de medio siglo de investigación arqueológica Cuad Tec de Patrim 11:11-28

Schiffer M (1983) Toward the identification of formation processes. Am Antiq 48:675-706

Seco de Lucena L (1961) Documentos árábigo-granadinos: edición crítica del texto árabe y traducción al español con introducción, notas, glosarios e índices. Instituto Egipcio de Estudios Islámicos en Madrid, Madrid

Silberberg M, Silberberg R (1971) Steroid hormones and bone. In: Bourne G (ed) The biochemistry and physiology of bone. Vol. III, 2nd. ed. Academic Press, London, pp 401-484 
Silver A (1969) The ageing of domestic animals. In: Brothwell D, Higgs ES (eds) Science in Archaeology: a survey of progress and research, 2nd edn. Thames \& Hudson, London, pp 283-302

Simpson GG, Roe A, Lewontin RC (1960) Quantitative zoology. Harcourt, Brace and World, New York

Symmons R (2004) Digital photodensitometry: a reliable and accessible method for measuring bone density. J Archaeol Sci 31:711-719

Symmons R (2005) Bone density variation between similar animals and density variation in early life: implications for future taphonomic analysis. In: O’Connor T (ed) Biosphere to Lithosphere: new studies in vertebrate taphonomy. Oxbow, Oxford, pp 86-93

Tito J (2018) Los estanques palatinos en el Occidente musulmán: La Favara de Palermo y el Albercón de Cartuja en Granada. In: Navarro J, Trillo C (eds) Almunias. Las fincas de las élites en el Occidente Islámico: poder, solaz y producción. Editorial UGR, Granada, pp 593-628

Torres FM (2007) Libro del principio, fundación y prosecución de la Cartuxa de Granada. Granada, Editorial UGR

Trillo C (2003) Aynadamar: la primera acequia de madina Garnata. TST Tran Serv Telecom 6:66-85

Trillo C (2018) Fincas de recreo de la Granada nazarí según las fuentes castellanas: El Nublo, La Alberzana y cármenes de Aynadamar. In: Navarro J, Trillo C (eds) Almunias. Las fincas de las élites en el Occidente Islámico: poder, solaz y producción. Editorial UGR, Granada, pp 573-592

Tristán F (2004) Ganadería y mercado de carne. La intervención concejil y sus problemas de abasto en Baza durante el siglo XVI. In: Barrios M, Galán Á (eds) La historia del Reino de Granada a debate. Viejos y nuevos temas. Perspectivas de estudio. Centro de Ediciones de la Diputación de Málaga, Málaga, pp 209-244
Turatti R Bermejo A Fernández-Reinoso MB Betsué I Blanca L and Blanca L (2016) Intervención multidisciplinar para la recuperación y puesta en valor de un horno del s. XVII en El Campus Universitario de Cartuja (Granada). In: El Patrimonio arqueológico: de las trincheras a la sociedad. La Granada invisible. Granada, pp. 195-198.

Villarino E (2015) Aproximación al estudio de la cerámic anazarí en las áreas periurbanas de Granada. El caso de Aynadamar @ rq y Territ $12: 221-235$

Villarino E, Moreno-Pérez AS, García-Contreras G (2016) Un elemento arquitectónico monumental posiblemente perteneciente a la Cartuja Vieja de los terrenos de Aynadamar (Granada). Rev del Cent de Estud Hist de Grana y su Rein 28:214-224

Wattenmaker P (1987) Town and village economies in an early state society. Paléorient 13:113-122

Yravedra J (2008) Informe arqueozoológico y tafonómico del yacimiento de El Pelícano. Sectores 1, 2, 4 y 9. Unpublish report.

Zeder MA (1988) Understanding urban process through the study of specialized subsistence economy in the Near East. J Anthropol Archaeol 7:1-55. https://doi.org/10.1016/0278-4165(88)90006-2

Zeder MA (1991) Feeding cities. Specialized animal economy in the ancient near East. Smithsonian Institution Press, Washington

Zeder M, Lapham H (2010) Assessing the reliability of criteria used to identify postcranial bones in sheep, Ovis, and goats, Capra. J Archaeol Sci 37:2887-2905. https://doi.org/10.1016/j.jas.2010.06.032

Publisher's note Springer Nature remains neutral with regard to jurisdictional claims in published maps and institutional affiliations. 